\title{
ZNIEMCZONY HOLLYWOOD W PRADZE RECEPCJA „NIEMIECKICH WERSJI” A POPULARNOŚĆ FILMÓW ZAGRANICZNYCH W PRASKICH KINACH NA POCZĄTKU LAT TRZYDZIESTYCH XX WIEKU
}

Niniejsze studium ${ }^{1}$ poświęcone jest obecności i recepcji zagranicznych filmów na czechosłowackim rynku w okresie wczesnej kinematografii dźwiękowej. Głównym przedmiotem badań są tu tzw. niemieckie wersje głównie amerykańskich filmów, na których przykładzie spróbuję ukazać relatywną popularność produkcji niemieckiej i amerykańskiej z uwzględnieniem ich atrybutów kulturowych, a nie jedynie językowych. Niemieckie wersje, pokazywane w praskich kinach w latach 1929-1934, odegrały istotną rolę w publicznej polemice dotyczącej kulturalnych i politycznych aspektów filmu dźwiękowego, jak również w dyskusjach o międzynarodowej orientacji czechosłowackiego rynku filmowego i czechosłowackiej produkcji. Często uważane były za zagrożenie dominacji języka czeskiego w sferze publicznej oraz przyszłego istnienia kinematografii czechosłowackiej jako takiej.

\section{Popularność filmu jako narzędzie historii recepcji}

Kiedy w studiach historycznych traktujących o handlu filmami ustalało się udział produkcji różnych proweniencji oraz rolę importerów na rynkach lokalnych, zwykle opierano się na danych o cenzurowanych filmach i o liczbie tytułów zgłaszanych do dystrybucji. Z takiej interpretacji statystyk na ogół wynikał wniosek o długotrwałej dominacji Stanów Zjednoczonych na poszczególnych narodowych rynkach filmowych Europy od lat 20. do współczesności, dominacji przerywanej jedynie chwilowymi zmianami regulujących import przepisów w różnych państwach (wskazać tu należy np. na kontyngenty, kwoty i następujący

1 Studium powstało dzięki wsparciu Agencji Grantów Republiki Czeskiej (projekt grantowy zarejestrowany pod numerem 408/03/D174). Chodzi o zmienioną i rozszerzoną wersję referatu The Practicies of Exhibition and Reception of German Films in Czechoslovakia of the Early 1930s, przedstawionego na konferencji 18. Internationaler Filmhistorischer Kongress (Cinegraph, Hamburg,16-20.11.2005). 
w wyniku ich wprowadzenia amerykański bojkot europejskich rynków w okresie wczesnego filmu dźwiękowego, później zaś na ograniczenia w okresie II wojny światowej oraz planowanie centralne i orientację programową na określone państwa w okresie panowania komunistycznego reżymu totalitarnego) ${ }^{2}$. Jak pokazał w mającym przełomowe znacznie studium o roli amerykańskich filmów w Niemczech (a w czasach powojennych w Republice Federalnej Niemiec) w latach 1925-1955 Joseph Garncarz, takie podejście zaczyna się wydawać problematyczne przede wszystkim w chwili, kiedy z ilościowej podaży filmów wyciąga się wnioski dotyczące największego sukcesu handlowego, preferencji widowni i ogólnej ekonomicznej i kulturalnej supremacji Hollywood w Europie ${ }^{3}$. Garncarz dokonał radykalnej zmiany, jeśli chodzi o posługiwanie się źródłami i danymi statystycznymi: poddawszy krytyce i ocenie dostępne informacje o handlowych rezultatach dystrybucji, sprzedaży biletów, czasie grania tytułu w kinach i upodobaniach widzów (przeważnie ich świadectwem były listy popularności w pismach poświęconych kinu i wykazy nagród filmowych), i doszedł do wniosku, że w Niemczech aż do roku 1971 wyraźnie najpopularniejsze były filmy niemieckie, a nie amerykańskie, $i$ to one przynosiły największe zyski. Wprawdzie już od lat 60. przebiegał proces amerykanizacji produkcji niemieckiej i sukcesywnego skłaniania się publiczności do amerykańskiego kina gatunkowego, ale pod względem sukcesu komercyjnego i popularności Hollywood zaczął dominować dopiero w następnym dziesięcioleciu. Jeśli przedtem jakieś hollywoodzkie filmy dostawały się do „pierwszej dziesiątki”, chodziło o obrazy, które w ten czy inny sposób odpowiadały normom niemieckiej kultury popularnej (dzięki tematowi, gatunkowi, typowi gwiazd aktorskich itp.). Ta konkluzja może prowadzić do dalekosiężnej zmiany szeroko przyjmowanego przekonania o globalnej hegemonii Hollywoodu jako uniwersalnej formy rozrywki ${ }^{4}$.

2 Zob. Z. Štábla, Vývoj filmového obchodu za Rakouska-Uherska a Československé republiky (1906-1939), [w: Filmový sbornik historický 3, red. Ivan Klimeš, ČFU: Praha 1992, s. 5-48; G. Heiss, I. Klimeš, Kulturní průmysl a polityka. Československé a rakouské filmové hospodařství v politické krizi trícátých let/Bilder der Zeit. Tschechischer und österreichischer Film der 30er Jahre, Praha-Brno: NFA-Rakouský ústav pro jihovýchodní Evropu, odbočka Brno-PVS Verleger 2003, s. 302-391; z publikacji zagranicznych por. np. K. Thopson, Exporting Entertainment: America in World Film Market, 1907-1934, BFI: London 1986.

3 J. Garncarz, Hollywood w Niemczech. Rola amerykańskich filmów w Niemczech w latach 1925-1990, w niniejszym tomie. Do publikacji Garncarza niedawno nawiązał P. Krämer w artykule Hollywood in Germany: Notes on a History of Cultural Exchange, przedstawionym na konferencji Media in Transition: Globalization and Convergence, Massachusets Institute of Technology, Cambridge MA, 10-12 May 2002. W sieci: http:// ems.mit.edu/confl/mit2/Abstracts/PeterKramer.pdf.

4 Por. np. studium Richarda Maltby'ego i Ruth Vasey, „Temporary American Citizens": Cultural Anxieties and Industrial Strategies in the Americanisation of European Ci- 
Przesunięcie uwagi z danych o dystrybucji i cenzurze na dane o sukcesie komercyjnym i preferencjach widzów, które jest podstawowym metodologicznym punktem wyjścia niniejszego studium, może się przyczynić do przewartościowania całościowego obrazu narodowej kultury filmowej. Prezentacja i recepcja bowiem określają tożsamość kinematografii narodowej w nie mniej istotny sposób niż sfera produkcji albo tradycja narodowa obecna w filmach jako tekstach kultury $^{5}$. W niniejszej pracy wyznaczono sobie jednak cel skromniejszy. Analiza popularności produktów filmowych według ich proweniencji narodowej w praskich kinach w latach 1929-1934 nie może tu zostać przeprowadzona w całej pełni i kompleksowo, ponieważ dla wykonania tego zadania trzeba by zdobyć jeszcze inne typy danych, na co dotychczas wykorzystywane przeze mnie źródła nie pozwalają. Skoncentruję się jedynie na uproszczonym kryterium popularności, mierzonej przeciętnym okresem prezentacji $\mathrm{w}$ premierowych kinach praskich, który zrekonstruuję na podstawie dostępnych danych statystycznych i z którego pomocą postaram się określić relatywne różnice popularności najważniejszych produkcji narodowych na miejscowym rynku w danym odcinku czasowym.

Jak pokazały badania historyka filmu brytyjskiego lat 30., Johna Sedgwicka, używającego do swych obliczeń tzw. indeksu POPSTAT, popularność filmów na określonym rynku narodowym trzeba oceniać na podstawie szeregu kolejnych parametrów, uzyskanych przede wszystkim dzięki pieczołowitej dyferencjacji cykli dystrybucyjnych kin: należałoby uwzględnić rozróżnienie na przedpremiery, premiery, wznowienia i ponowne prezentacje, wielkość kina, jego status komercyjny na rynku filmowym (to znaczy stosunek do dystrybutorów: czy kino zwykle przedstawia filmy przedpremierowe, premierowe czy wznowienia; jaka jest związana z tym cena biletów), potencjalną wysokość utargu, poziomą strukturę własności kin i tzw. pionową integrację (powiązania między producentami, dystrybutorami i sieciami kin) ${ }^{6}$. Zastosowanie tego modelu wymagałoby dalszych samodzielnych badań, toteż ograniczę się tu do ogólnych i globalnych oszacowań

nema, [w:] „Film Europe” and "Film America”. Cinema, Commerce and Cultural Exchange 1920-1939, eds. A. Higson, R. Maltby, University of Exeter Press: Exeter 1999, s. 32-55. Jego autorzy opierają się jednak przeważnie na źródłach brytyjskich, a Wielka Brytania w tej kwestii prawdopodobnie różniła się od Niemiec i innych krajów europejskich, stopień popularności filmów brytyjskich i amerykańskich był tu w latach 30. mniej więcej taki sam. Zob. J. Sedgwick, Cinema-going Preferences in Britain in the 1930s, [w:] The Unknown 1930s: An Alternative History of British Cinema 1929-1939, ed. J. Richards, I.B. Tauris: London-New York 1998, s. 1-36.

${ }^{5}$ Por. A. Higson, The Concept of National Cinema. „Screen” 1989, Vol. 30, No. 4, s. $36-46$.

${ }^{6} \mathrm{~W}$ równaniu Sedgwicka także figuruje czas grania filmu, ale tylko jako jedna ze zmiennych. Por. J. Sedgwick, Cinema-going... 
popularności poszczególnych całostek produkcji narodowych (nie zaś konkretnych gwiazd, gatunków lub producentów, co uwzględnia Sedgwick), kryterium będą obliczenia przeciętnej długości premierowej prezentacji w Pradze (w tygodniach, przy czym jeśli premiera odbyła się $\mathrm{w}$ większej liczbie kin, podaję sumę tygodni). Taką metodę usprawiedliwiam tym, że przy utrzymaniu homogeniczności szablonu (fabularne filmy dźwiękowe grane w praskich kinach premierowych) i wysokiego poziomu ogólności (produkcje narodowe jako całość) minimalizuje się blędy wynikające z nierozróżniania innych parametrów.

Zaletą informacji zawartych $\mathrm{w}$ gospodarczych podsumowaniach Jiř́ego Havelki ${ }^{7}$, którymi się tu posługuję, jest to, że są stosunkowo nieselektywne i homogeniczne: obejmują wszystkie przedstawiane w kinach premierowych filmy. Wadą danych Havelki zaś jest ograniczenie się tylko do premier filmów dźwiękowych przeważnie w premierowych kinach stolicy (bez uwzględnienia wznowień, prezentacji filmów niemych oraz mniejszych i pozapraskich kin), dzielenie materiału zgodnie $\mathrm{z}$ latami kalendarzowymi a nie $\mathrm{z}$ sezonami, a przede wszystkim absencja informacji o frekwencji i zyskach z prezentacji filmów według ich proweniencji narodowej; te informacje Havelka zaczyna selektywnie podawać dopiero w bilansie roku 1937, a tymczasem gdyby udało się je zrekonstruować, mogłyby pomóc uściślić wnioski wyciągane z przeciętnej długości grania danego filmu.

Metoda oceny popularności na podstawie przeciętnej długości prezentacji $\mathrm{w}$ kinach premierowych z pewnością nie należy do najdokładniejszych (najdokładniejsze jest kryterium sukcesu kasowego, czego dowodzi Sedgwick). Dodajmy, że nie jest ona bynajmniej rzadka ani dziwna, wykorzystał ją sam Havelka ${ }^{8}$, a z czeskich historyków filmu Zdeněk Štábla ${ }^{9}$, stosowano ją też w statystykach zagranicznych, na przykład na listach popularności w niemieckim piśmie fachowym „Filmblätter”. Jeśli chodzi o nastawienie na nowości filmowe w Pradze, to Havelka nie bez kozery wybrał je do swych statystyk czasu grania poszczególnych obrazów. Ogromna większość tych premier odbywała się w tzw. salach premierowych, które, rzecz jasna, nie mogą reprezentować całego spektrum kin, ale wobec niedostatku innych źródeł dają relatywnie czysty wzór, dobry do analizy, zwłaszcza w warunkach kraju, w któtym sieć kinowa była mocno heterogeniczna, a integracja pionowa nie istniała ${ }^{10}$. Ta grupa mniej więcej dwudziestu dwóch kin

7 J. Havelka, Čs. filmové hospodařství I. Zvukové období 1929-1934, Čefis: Praha 1935.

8 Idem, Čs. filmové hospodařství IV, Knihovna filmového kurýru: Praha 1938, s. 67.

9 Z. Štábla, Vývoj filmového obchodu..., s. 28.

10 Fakt, że kina prowadziły u nas stowarzyszenie, a nie wytwórnie filmowe, to jeszcze jeden powód, by uznawać przeciętny czas grania filmu za relatywnie pewny wskaźnik popularności, ponieważ dzięki temu obniża się prawdopodobieństwo nierynkowych manipulacji ze strony kin na rzecz filmów określonej proweniencji. 
nie powstała przypadkiem ani ad hoc, chodziło o instytucje mające własną organizację, mianowicie Stowarzyszenie Kin Premierowych (Sdružení premiérových kin), agendę Głównego Związku Kinematografów (Ústřední svaz kinematografu), który stawiał na „wspólne działania i wspólną politykę cenową”"11.

Wyliczenie przeciętnej długości grania filmu nie może zastąpić badania popularności ani recepcji kulturowej w ich całokształcie, dostarcza jednak wyobrażenia o inklinacjach krajowej publiczności i jej stosunku do poszczególnych narodowych i językowych kategorii filmowej podaży oraz o przemianach tych inklinacji w okresie tzw. wczesnego filmu dźwiękowego. Najważniejszym wkładem tych nowo wygenerowanych informacji jest to, że przynoszą rozwiązanie jakościowe, inne niż na ogół proponowane dane ilościowe mówiące o obecności poszczególnych importerów na czeskim rynku filmowym; przesunięcie akcentu $\mathrm{z}$ dystrybucji na przedstawianie filmu pomoże doprecyzować niektóre wyobrażenia o pozycji filmów różnej proweniencji narodowej na czeskich ekranach.

Najważniejsza różnica między tworzeniem bloków filmów - z jednej strony - w celu ustalenia popularności, z drugiej zaś dla potrzeb zwykłych filmografii, to inne datowanie: zasadą grupowania i datowania filmów może być tu jedynie moment premiery, a nie rok produkcji albo data zezwolenia na dystrybucję, te ostatnie bowiem nie mają żadnego wpływu na recepcję (chociaż sam wiek filmu wpływ taki ma, było tak zwłaszcza w okresie błyskawicznych przemian technicznych na początku lat 30.). Różnice powstałe w wyniku tej zmiany zasady są poważniejsze niż mogłoby się wydawać, ponieważ często dochodziło do tego, że film był przedstawiany wiele miesięcy po przejściu przez krajową cenzurę (nierzadko dopiero w następnym roku), w wyjątkowych przypadkach mogło dojść nawet do opóźnienia kilkuletniego. Drugą specyficzną właściwością użytych poniżej danych jest wprowadzenie osobnej kategorii na mówione po niemiecku wersje amerykańskich, brytyjskich, francuskich i innych zagranicznych produkcji, co może uszczegółowić obraz preferencji widzów w odniesieniu do filmów według proweniencji narodowej. Przy ocenie danych o liczbie i prezentacji tych wersji trzeba jednak uwzględnić fakt, że podsumowania Havelki, które służyły mi jako główne źródło informacji, pod nazwą ,,wersja” zawierają nie tylko tzw. wersje wielojęzykowe (multiple-language versions), ale również dubbing i synchronizację komentarza zza kadru w filmach dokumentalnych. Trzecia z dołączonych do niniejszego tekstu tabel zawiera listy najpopularniejszych dźwiękowych filmów fabularnych, granych w praskich kinach premierowych w latach 1929-1934. Ten rodzaj podsumowania, dokonanego na podstawie danych tego samego typu, pozwoli wzbogacić gamę produkcji narodowych o czynnik konkretnych przebojów komercyjnych.

${ }^{11}$ J. Havelka, Čs, filmové hospodařství IV, s. 67. 
Historia recepcji filmów i preferencji widzów pozwala też uwzględnić propozycje współczesnej społecznej i kulturowej historiografii kina (inspirowanej przez Szkołę Annales), która proponując swój model multitemporalnych i wielowymiarowych dziejów kinematografii, wprowadziła kwestię porównania różnych historycznych perspektyw (mikro/makro, lokalne/globalne) i wielości czasów historycznych i która próbuje rozwiązywać problemy wielkich całości za pomocą tworzenia serii homogenicznych danych. Na przykład włoski historyk filmu Gian Piero Brunetta podkreśla, że na różnych płaszczyznach kinematografii znajdują zastosowanie różne czasowe szybkości: czas przemian języka artystycznego różni się od rytmu zmian technicznych, przesunięć w poglądach krytyków czy od „biorytmów" publiczności i inercji życia społecznego jako całości ${ }^{12}$. Zgodnie z tym wyobrażeniem braudelowskiemu krótkiemu trwaniu odpowiadałyby jednorazowe wydarzenia, jak na przykład oczarowanie technicznym wynalazkiem dźwięku synchronicznego, pierwszeństwo amerykańskich filmów mówionych w Europie, wprowadzenie kontyngentu ${ }^{*}$ czy niepokoje publiczne wyrażające protest przeciwko językowi niemieckiemu w kinach czeskich, podczas gdy w warstwie głębszej, w rytmie długiego trwania czasu społecznego działałyby tendencje rozwojowe mentalności, nawyków i inklinacji określonych grup widzów, całości geopolitycznych i szerszych struktur społecznych. W przypadku kinematografii czeskiej początku lat 30. można różnym szybkościom czasowym przyporządkować różne plaszczyzny konstruowania tożsamości narodowej i preferencji międzynarodowych.

\section{Prezentacja filmów zagranicznych i frekwencja w kinach}

W krótkim okresie drugiej połowy roku 1929 i pierwszej połowy 1930, kiedy szybko zostały udźwiękowione dziesiątki kin na terytorium Czechosłowacji, choć nie zainstalowano jednocześnie aparatury dźwiękowej w żadnej z krajowych wytwórni, wydawało się, że czeski rynek filmowy będzie zorientowany przede wszystkim na Stany Zjednoczone. Jak dobrze wiadomo, w 1929 roku doszło do ekspansji hollywoodzkich talkies w większości krajów Europy Zachodniej, gdzie filmy te zdobyły ogromną popularność jako nowinki techniczne i spowodowały przyśpieszenie rozwoju własnej produkcji obrazów dźwiękowych. Jeśli przyjrzymy się liczbom dotyczącym projekcji filmów dźwiękowych w roku 1929 w Pradze, przekonamy się, że do największych szlagierów należały zdecydowanie produkcje amerykańskie, które osiągały aż dwanaście tygodni projekcji w kinach

12 Por. G. P. Brunetta, History and Historiography of Cinema, „Cinema \& Cie” 2001, No. 1, s. 98-108; G. Lacasse, Cent temps de cinema ou le cinema dans les temps de l'historie. „Cinémas” (numer specjalny „Les Temps au cinema”) 1994, Vol. 5, No. 1-2 (automne), s. $15-39$. 
premierowych (Śpiewajacy błazen**, Biate cienie). Nawet odnoszące największe sukcesy czeskie nieme filmy z roku 1929 grane były znacznie krócej: sześć tygodni pokazywano w stolicy Erotikon i Praskie szwaczki (Pražské švadlenky) ${ }^{13}$.

Już jednak w następnym roku sytuacja gwałtownie się zmieniła. Do kin trafily pierwsze dźwiękowe filmy niemieckie i natychmiast zdobyły wielką popularność, przy czym najbardziej rzucającą się w oczy grupą szlagierów stały się filmowe operetki Gézy von Bolváry (Dwoje serc $w$ takcie na trzy czwarte, 17 tygodni, Koniec pieśni, 8 tygodni, Tango dla ciebie, 7 tygodni). Filmy amerykańskie utrzymały przewagę kwantytatywną i często stale odnosiły sukcesy (Parada mitości, $\mathrm{Na}$ zachodzie bez zmian), ale nie tak spektakularne, jak Dwoje serc w takcie na trzy czwarte, i przeciętnie grane były o tydzień krócej niż filmy niemieckie. Mniej więcej dwudziestosiedmioprocentowa różnica w popularności filmów niemieckich i amerykańskich utrzymała się potem jako konstanta w całym okresie wczesnego filmu dźwiękowego, to znaczy do roku 1934. Obliczenia dotyczące przeciętnego czasu wyświetlania w kinach premierowych różnych produkcji zagranicznych (amerykańskich, niemieckich, francuskich, brytyjskich) dowiodły, że filmy niemieckie były w tym okresie bezkonkurencyjnie najpopularniejsze i to mimo antyniemieckich wycieczek dziennikarzy i polityków oraz mimo akcji nacjonalistów w kinach i na ulicach w połowie roku $1930^{14}$. Przeciętny czas wyświetlania filmów amerykańskich w roku 1930 wynosił 2,5 tygodnia, a w wypadku niemieckich 3,4, zaś czeskie filmy dźwiękowe z 9,6 tygodnia osiągnęły bezdyskusyjnie największą popularność w całej gamie produkcji narodowych. Do spektakularnych szlagierów należały Fałszywy marszałek (C. a K. polní maršalek) ${ }^{* * *}$ i Szewskie święto (Fidlovačka); pierwszy z nich stał się symbolem nieoczekiwanego tryumfu produkcji krajowej. Popularność czeskich filmów w stosunku do obrazów pochodzących z innych krajów wprawdzie w kolejnych latach spadała proporcjonalnie do wzrostu liczby produkowanych w Czechosłowacji tytułów, ale i tak suwerennie utrzymały one pierwszą pozycję.

W latach 1930-1934 w praskich kinach dało się w stosunkowo dużej mierze zauważyć nowe zjawisko, które mogło dostarczyć dodatkowy klucz do ustalenia tożsamości narodowej czeskiej publiczności filmowej i jej preferencji międzynarodowych. W roku 1930 do dystrybucji trafil pierwszy zestaw nieniemieckich filmów w niemieckim opracowaniu językowym. Nasuwa się pytanie, czy kalkulacje

${ }^{13}$ Pewną rolę w ekstremalnej długości wyświetlania w premierowych kinach filmów amerykańskich mógł odgrywać brak szerszej oferty, niemieckie filmy dźwiękowe dotarly do Pragi w roku 1930, a dopiero co udźwiękowione kina musiały szybko postarać się zdobyć pieniądze na spłatę kredytów przeznaczonych na zakup aparatury dźwiękowej.

${ }_{14}$ Por. N. M. Wingfieldová, Film jako otázka národní identity, „Iluminace” 1996, vol. 8, nr 4, s. 8 . 
niektórych producentów i dystrybutorów zagranicznych, zakładających większą inklinację miejscowej publiczności do niemieckiego niż angielskiego lub jakiegokolwiek innego języka obcego, odzwierciedlały rzeczywiste preferencje czeskich widzów.

Praktyki przedstawiania zagranicznych filmów na rynku czechosłowackim można schematycznie podzielić na siedem kategorii; wszystkie te kategorie były obecne w praskich kinach już od roku 1930:

- oryginalne wersje z napisami;

- wersje językowe;

- dubbing;

- postsynchronizacja komentarza w filmach dokumentalnych;

- tzw. wersje międzynarodowe czy kontynentalne, ewentualnie wersje kombinowane (wersje dźwiękowe ze śpiewem, ruchami i nieartykułowanymi wypowiedziami, gdzie nieśpiewane obcojęzyczne dialogi zastępowane są muzyką i napisami);

- wersje oryginalne z czeskimi wstawkami;

- nieme wersje filmów dźwiękowych.

Jak pośrednio dowodzą wyraźne skargi na brak napisów dialogowych $\mathrm{w}$ dziennikarskich tekstach zamieszczanych w czeskich gazetach, opatrywanie napisami zagranicznych filmów było w Pradze najpóźniej od 1930 roku ogólnie przyjmowaną normą, aczkolwiek niektóre z pierwszej fali filmów dźwiękowych, granych w drugiej połowie roku 1929 i w 1930, mogły być pokazywane bez przekładu albo z minimalną ilością napisów. Dziennikarze uważali czeskie napisy za standard i pisali o nich tylko w przypadku, kiedy chcieli zwrócić uwagę na ich brak lub skrytykować zły przekład czy błędy językowe ${ }^{15}$. Jeśli pominiemy tę standardową kategorię, czyli wersję oryginalną z napisami, za najważniejszą i najszerzej dyskutowaną z punktu widzenia recepcji należy uznać grupę filmów prezentowanych w roku 1930 oraz trochę wcześniej i później jako „czeskie wersje", nie tyle czeskie wersje językowe (w znaczeniu multiple-language versions) ${ }^{16}$, ile raczej wersje z czeskimi wstawkami i tzw. wersje międzynarodowe ${ }^{17}$. Ogólnie

${ }^{15}$ Na przykład dystrybutor niemieckiej wersji filmu Atlantic był wielokrotnie krytykowany za to, że dostarczył kopię bez czeskich napisów. Zob. Odpor proti německým zvukovým filmům. Nové snahy po třech porażkach nëmecké verse, „České slovo” 1930, 14 březen, nr 63, s. 9; J. V. J., Atlantic bricht alle Rekorde (Ale o jeho osud metali los...), „České slovo” 1930, 7 březen, nr 57, s. 15.

${ }^{16}$ Takie przygotowano tylko cztery; są to trzy czeskojęzyczne wersje filmów wyprodukowane przez wytwórnię Paramount w studiach w Joinville - Tajemnica lekarska (czes. Tajemství lékařovo), Świat bez granic (czes. Svèt bez hranic) i Śmiejąca się kobieta (czes. Žena, která se směje) - oraz Štvanílidé (Szczuci ludzie), czeska wersja Gehetzte Menschen Friedricha Fehéra.

${ }^{17}$ Do licznych wersji międzynarodowych należały na przykład niemal wszystkie produkcje wytwórni Fox z roku 1930, jak również niektóre tytuly innych amerykańskich 
można powiedzieć, że język angielski rozbrzmiewał w praskich kinach rzadziej niż można by się tego spodziewać na podstawie liczby importowanych filmów, ponieważ w wersjach międzynarodowych mowa zastępowana była synchronizowaną muzyką i napisami. Najważniejszą - z punktu widzenia recepcji - grupę filmów należącą do kategorii wersji językowych w węższym znaczeniu tworzyły nie wersje mówione po czesku, ale wersje niemieckie filmów amerykańskich, wyprodukowane przez producentów z USA. To samo można powiedzieć o dubbingu: pierwsze filmy fabularne $\mathrm{z}$ czeskim dubbingiem przedstawiono $\mathrm{w}$ roku 1934, ale pierwszy film amerykański z dubbingiem niemieckim grano w Pradze już w styczniu 1930. Inna była sytuacja w dziedzinie pełnometrażowych filmów dokumentalnych, w latach $1930-1934$ pokazano aż 70 procent zagranicznych tytułów w wersjach oryginalnych i niemal 30 procent $(12 \mathrm{z} 42)$ z postsynchronizowanym komentarzem czeskim, a tylko jeden amerykański dokument przełożony był na niemiecki.

Według moich obliczeń, dla których potrzeby posługiwałem się zarówno statystykami Havelki, jak i wzmiankami o ścieżkach dźwiękowych cenzurowanych filmów w „Biuletynie Ministerstwa Spraw Wewnętrznych” („Věstník ministerstwa vnitra") ${ }^{18}$, w latach 1930-1934 do praskich kin trafiło 50 niemieckich

producentów grane w Pradze w latach 1930 i 1931; przykładem niech będą tu Mężczyźni bez kobiet (Men Without Women, czes. Ponorka S 13) Johna Forda czy Szczęśliwe dni (Happy Days, czes, Karneval umëlců) z Charlesem Farrellem, wyprodukowane przez Foxa, czy Statek komediantów (czes. Lod' komediantů) Universalu, niekiedy też filmy niemieckie (na przykład Sensacja Karla Lamača), ale także zagraniczne kroniki filmowe z roku 1930. Zob. comiesięczne wykazy ocenzurowanych filmów (Filmové hlídky, w: Věstník ministerstwa vnitra Republiky československé). W kwestii dyskusji o wersjach międzynarodowych por. ksž [Karel Smrž], Všechny předvádèné Foxovy filmy..., „Rozpravy Aventina” 1930, 5 červen, nr 36, s. 461; ksž [Karel Smrž], Předvádění Foxfilmu..., „Rozpravy Aventina” 1930, 9 řijen, nr 3, s. 34-35; ksž [Karel Smrž], Rozdil mezi pưvodní mluvenou verzi..., „Rozpravy Aventina” 1930, 19 listopad, nr 9, s. 106. Do najszerzej komentowanych filmów z czeskimi wstawkami należały Hollywood Revue i Paramount Revue, ale czeskie wstawki czy prologi pojawiały się i w innych tytułach.

${ }^{18}$ Spisy filmów dopuszczonych do czechosłowackiej dystrybucji lub, przeciwnie, zakazanych przez cenzorów, byly publikowane w tzw. „Filmowej rubryce” (Filmová hlídka) „Biuletynu Ministerstwa Spraw Wewnętrznych Republiki Czechosłowackiej”. W spisach zawartych w „Filmowej rubryce” już od drugiej połowy 1930 roku pojawiały się cenne uściślające informacje o ścieżce dźwiękowej, np. „dźwiękowy z niemieckim dialogiem”, „dźwiękowy bez dialogu”, „dźwiękowy z czeskim wstępem i angielskim dialogiem”, „dźwiękowy z angielskim dialogiem i francuskimi piosenkami”, „dźwiękowy z częściowo angielskim, częściowo niemieckim dialogiem”. Dzięki porównaniu z ówczesnymi reklamami i z podsumowaniami Havelki, gdzie poza wyjątkowymi przypadkami określone są wszystkie „wersje”, można osiągnąć znaczną ścisłość w rozróżnianiu zagranicznych filmów z czeskimi wstawkami, „wersji międzynarodowych” oraz wersji językowych lub dubbingu. 
wersji zagranicznych fabularnych filmów pełnometrażowych. Jedenaście z nich było dubbingowanych lub opatrzonych zsynchronizowanym komentarzem, dwa były wyprodukowane tylko w niemieckiej wersji, pozostałe były niemieckimi realizacjami wersji wielojęzykowych. Największą grupę tworzyły filmy wyprodukowane i dystrybuowane przez wytwórnie amerykańskie i ich filie: Paramount (11), MGM (7), Fox (4), kolejną dobrze widoczną grupę stanowiły produkcje spółki British International Pictures (6), których dystrybucję w Czechosłowacji zapewniała firma Slavia.

Pozycja wersji niemieckich $\mathrm{w}$ praskich kinach zdecydowanie zmieniła się na przełomie lat 1934 i 1935. W rozporządzeniu Ministerstwa Handlu nr 131,126/34 z 14 listopada 1934 (z uzupełnieniem nr 6320/35 obowiązującym od 24 stycznia 1935) ustalono, że na import filmu „zezwoli się jedynie w językowej wersji czechosłowackiej i w językowej wersji kraju pochodzenia”. Odpowiedni paragraf dotyczył dubbingu: „Dubbingowanie importowanych filmów w celu przedstawiania ich $\mathrm{w}$ Czechosłowacji z użyciem innego języka dozwolone jest tylko w przypadku, kiedy filmy te były dubbingowane przede wszystkim $\mathrm{z}$ użyciem języka czechosłowackiego ${ }^{\text {"**** }}$. Jednoznacznie ustalano tu także obowiązek opatrywania napisami wszystkich zagranicznych filmów z oryginalną ścieżką dźwiękową: „Wszystkie kopie importowanych filmów, prezentowane w językowej wersji którejś z mniejszości narodowych, muszą być opatrzone napisami w języku czechosłowackim. Napisy winny być przygotowane w kraju”. Ogłoszenie określało również możliwości wyjątków związanych ze specyficznymi sytuacjami. O jaki typ wyjątków chodziło przede wszystkim, widać w następującej wersji rozporządzenia z 23 stycznia 1937: „Filmy z dubbingiem niemieckim mają być prezentowane tylko w miejscach, gdzie mieszka więcej niż 50 procent osób narodowości niemieckiej"19. Havelka w komentarzu do tego postanowienia podaje, że zakazowi mają podlegać przede wszystkim niemieckie wersje filmów amerykańskich $^{20}$. W roku 1935 cenzura dopuściła jeszcze do dystrybucji 16 takich wersji filmów amerykańskich, brytyjskich, francuskich i włoskich, ale żadna z nich nie doczekała się praskiej premiery. Zaprezentowano jedynie kilka produkcji węgierskich i duńskich, które Havelka nazywa wersjami niemieckimi. Wersje filmów amerykańskich i angielskich wróciły do praskich kin dopiero w roku 1938 (wersje sześciu obrazów amerykańskich i jednego angielskiego). W specyficznych warunkach podczas II wojny światowej niemieckie wersje nieniemieckich produkcji

19 J. Havelka, Čs. filmové hospodářství I, s. 5-9. Idem, Čs. filmové hospodářrství III. Rok 1936, Knihovna Filmového kurýru: Praha 1937, s. 19. Spis 342 miejsc ( 254 w Czechach, 78 na Morawach, 10 na Słowacji), gdzie wolno było wyświetlać niemieckie wersje, publikowany był w: idem, Seznam čs. kin podle stavu 1. května 1937, Knihovna Filmového kurýru: Praha 1937.

20 Idem, Čs. filmové hospodárství III, s. 40. 
(głównie włoskich i francuskich) dosłownie zalały czeskie kina, a nieniemieckie filmy zagraniczne w wersji oryginalnej stały się mniejszością ${ }^{21}$.

Starania o zakaz czy przynajmniej regulację przedstawiania wersji niemieckich w Pradze pojawiały się wprawdzie już przed rokiem 1934, ale nie były zbyt skuteczne. 26 września 1930 roku z inicjatywy Krajowego Związku Kinematografów (Zemský svaz kinematografü) wobec wrześniowych demonstracji utworzono Komisję ds. Dystrybucji Importowanych Filmów Dźwiękowych, w której zasiadali przedstawiciele Urzędu Ziemskiego, komendy policji, Izby Handlowej i Krajowego Związku Kinematografów. Zadaniem komisji było ograniczenie projekcji filmów z dialogami niemieckimi do trzech lub czterech premier w wielkiej Pradze $^{22}$. W grudniu tegoż roku Związek opublikował nadzwyczajne obwieszczenie, w którym nakazywał, by kina we wszystkich reklamach i programach podawały, jaką wersję językową wyświetlają i jaki jest język dialogów ${ }^{23}$. Komisja deklarowała też zakaz przedstawiania wszystkich wersji niemieckich, a w kwietniu 1932 oznajmiła, że „będzie bezwarunkowo trzymać się pierwotnego postanowienia, zgodnie z którym nie dopuści w Pradze do wyświetlania filmów produkcji amerykańskiej, angielskiej, francuskiej i innych, jeśli mają one dialogi niemieckie"24. $\mathrm{Na}$ podstawie tej enuncjacji można wywnioskować, że zakaz ten po raz pierwszy został wydany co najmniej o rok wcześniej i rozesłany właścicielom kin jako osobny okólnik. Jednakże działalność tej starającej się o samoregulację rynku komisji od początku spotykała się z niechęcią dystrybutorów, którzy chcieli eksploatować wszystkie zakupione przez siebie niemieckie wersje. Toteż wpływ komisji był słaby już w momencie jej założenia i słabł jeszcze bardziej od początku roku $1931^{25}$. Najlepszym dowodem prawdziwości tego twierdzenia jest spojrzenie na wykaz wersji niemieckich, które wyświetlano w latach 1931 i 1932 w praskich kinach (zob. tabelę 4. $)^{26}$. Od roku 1932 starania komisji stały się bezprzedmiotowe ze względu na wprowadzenie kontyngentu.

${ }^{21}$ Zob. idem, Filmové hospodárství v Zemich českých a na Slovensku 1939-1945, Čs. filmové nakladatelství: Praha 1946, s. 40.

22 Zdeněk Štábla, Data a fakta $z$ dějin Čs. Kinematografie 1896-1945, III, ČSFU (druk wewnętrzny) Praha 1990, s. 164; Komise pro distribuci dovážených zvukových filmů, „Filmový kurýr” 1930, 28 listopad, vol. 4, nr 48, s. 1.

${ }_{23}^{23}$ „Filmový kurýr” 1930, 5 prosinec, vol. 4, nr 49, s. 1.

${ }^{24} V$ Praze se nesměji předvádèt nèmecké verse, „Filmový kurýr” 1932, 29 duben, vol. 6 , nr 18 , s. 1.

${ }^{25}$ H., Kdo je vinen? „Filmový kurýr” 1931, 30 březen, vol. 5, nr 12, s. 1.

${ }^{26}$ Wyjątkowym wypadkiem był pod tym względem skandal związany z policyjnym zakazem niemieckiej wersji czeskiego filmu Afera putkownika Redla (Aféra plukovníka Redla). Zob. H., Tež̌ká prace distribuční komise, „Filmový kurýr” 1931, 13 březen, vol. 5, nr 11, s. 1 . 


\section{Zniemczony Hollywood: recepcja „wersji niemieckich”}

Popularność „wersji niemieckich” od początku aż do roku 1934, kiedy ich prezentacja w Pradze w gruncie rzeczy się skończyła, była zdecydowanie niska. Mimo to już w roku 1931 pojawiło się ich trzy razy więcej niż w poprzednim, co w wyraźny sposób pokazuje, jak producenci i dystrybutorzy oceniali tożsamość narodową czeskiej publiczności i charakter kulturowy lokalnego rynku ${ }^{27}$. W kolejnych latach liczba niemieckich wersji nieniemieckich filmów stopniowo spadała nieomal do zera ${ }^{28}$. Jedynym tytułem, który wszedł do grupy cieszących się największym powodzeniem obrazów była niemiecka wersja francuskiego filmu Nietoperz (La chauve-souris, niem. Die Fledermaus), która jednak swoją popularność zawdzięczała chyba temu, że grała w niej Anny Ondráková, a reżyserował ją Karel Lamač.

Niemieckie wersje miały szczególne znaczenie kulturowe w związku z obecnością języka angielskiego w czeskich kinach, co najlepiej widać na przykładzie stosunku do brytyjskich tytułów w okresie kontyngentu. Gdybyśmy oparli się na informacjach o dystrybucji, wydawałoby się, że brytyjskie wytwórnie, korzystające z embarga głównych eksporterów amerykańskich, wręcz zalały Pragę w tym czasie swoimi produktami, ale jeśli pominiemy niemieckie wersje brytyjskich filmów, okaże się, że brytyjska odmiana języka angielskiego rozbrzmiewała $\mathrm{w}$ czechosłowackich kinach sporadycznie, nawet rzadziej niż niemiecki w produkcjach nieniemieckich. Jednocześnie jednak jest oczywiste, że pod względem popularności niemieckie wersje nie mogły się równać z filmami amerykańskimi z oryginalną ścieżką dźwiękowa $\mathrm{i}$ - a różnica jest tu znacznie większa - z filmami produkcji niemieckiej. Czeska publiczność wyraźnie więc rozróżniała wartości kulturalne i estetyczne związane z filmami niemieckiej produkcji z jednej strony i filmami przełożonymi na niemiecki z drugiej i nie kierowała się tylko kryterium lepszej zrozumiałości.

Chociaż wielka część dziennikarzy prasy codziennej, a niekiedy nawet publicyści pism fachowych, zdawali się w swych publikacjach nie dostrzegać długotrwałej atrakcyjności produkcji niemieckiej dla czeskich widzów i podkreślali interesy narodowe i obawy przed tzw. germanizacją, w ówczesnej prasie pojawiały się też wypowiedzi, które dowodzą, że harmonia między czeską publicznością i produkcjami niemieckimi kontrastowała $\mathrm{z}$ obcością odczuwaną $\mathrm{w}$ stosunku do

27 Niemieckich wersji było wtedy w praskich kinach więcej niż filmów z USA i Niemiec oraz wszystkich innych krajów razem.

28 W roku 1932 natomiast zaczynają się mnożyć zagraniczne dokumenty przyrodnicze i podróżnicze z postsynchronizowanym czeskim komentarzem, z których to dokumentów pierwszy pojawił się już w 1930, a od roku 1934 filmy fabularne z czeskim dubbingiem. 
filmów amerykańskich, i że było to ogólnie znanym faktem. Jego świadomość znajdowała odbicie przede wszystkim w periodykach nastawionych krytycznie wobec prawicowych tendencji nacjonalistycznych, takich jak „Právo lidu” i „České slovo":

Widać, że mimo wszystkich politycznych sympatii i antypatii z okresu wojny i przewrotu, mimo masowych wyjazdów do krajów zachodnich, mimo pełnej entuzjazmu nauki francuskiego $i$ angielskiego w latach powojennych, stale tkwimy głęboko w sferze wpływów niemieckich, niemieckiej atmosfery ideowej i uczuciowej. Trzeba zobaczyć i usłyszeć, jaką rozkoszą reaguje na ten film czeska publiczność, kiedy słyszy niemiecki język, rozumie niemieckie słowo i niemiecki dowcip, nie musząc czekać na czeskie napisy. W wypadku angielskich i francuskich filmów dźwiękowych, choćby były artystycznie najwartościowsze, nigdy nie zetkniecie się z niczym podobnym. Niebezpieczeństwo tkwi obecnie przede wszystkim w tym, żeby wielka międzynarodowa produkcja filmowa, tworząca różnojęzyczne wersje, widząc ten niewątpliwy sukces niemieckiego filmu dźwiękowego u nas, nie włączyła automatycznie Pragi i Czechosłowacji do niemieckiej sfery odbiorczej. Po co ryzykować tworzenie wersji czeskich, zwiększając w ten sposób wydatki, skoro tak łatwo można u nas sprzedać wersję niemiecką $!^{29}$

Powyższy cytat pokazuje, że już w roku 1930 niemieckie wersje stały się szczególnym przedmiotem obaw w sferze kultury i że ogniskowała się na nich dyskusja o gospodarczej przyszłości kinematografii czechosłowackiej ${ }^{30}$.

Praktyka wyświetlania niemieckich wersji spotkała się w czeskiej prasie z przyjęciem jednoznacznie negatywnym i stała się powodem różnych działań ze strony związanych z kinematografią związków i stowarzyszeń, jak również urzędów państwowych. Niemieckie wersje zwłaszcza na początku (w roku 1930) jawiły się jako dowód na to, że zagraniczni producenci i dystrybutorzy mają tendencję do włączania Czechosłowacji do kategorii rynków niemieckojęzycznych i że - mimo rzekomych obietnic niektórych z nich - nie planują bardziej systematycznej produkcji wersji czeskich. Karel Smrž wymownie wyraził swoje rozgoryczenie, widząc zagrożenie zastąpieniem wersji oryginalnych tego rodzaju hybrydami na czeskim rynku:

29 O nèmeckých filmech a jejich nabezpečí kulturném, „České slovo” 1930, 25 září, nr 227, s. 5.

${ }^{30} \mathrm{~W}$ odróżnieniu od terminu multiple-language versions, który jest używany we współczesnych pracach z historii filmu, ówczesny termin „niemiecka wersja” odwoływał się do znacznie szerszego pola semantycznego, to znaczy do jakiegokolwiek zjawiska zastępującego pierwotny język filmu, przy czym termin „wersja” mógł mieć w ówczesnym dyskursie jeszcze bardziej ogólne znaczenie, a mianowicie mógł oznaczać jakikolwiek film, w którego wypadku określano sposób jego prezentacji (włączając w to „wersję oryginalną"). 
Jeśli tutejsza filia M.G.M. postanowi przedstawić ten film [Kobieta warta miłości, ang. A Lady to Love] na terytoriach niemieckich albo mieszanych, nie można nic temu pomysłowi zarzucić. Jeśli jednak miałby on być wyświetlany w Pradze albo $\mathrm{w}$ innych czeskich miastach, trzeba by przeciw jego prezentacji bardzo stanowczo zaprotestować. Nikt nie będzie się zastanawiał nad tym, że po niemiecku grany jest film wyprodukowany w Berlinie, ale jeśli pozwolimy na to, żeby mówione po angielsku filmy amerykańskie były u nas grane w wersjach niemieckich, sami zakwalifikujemy się do niemieckiej sfery i po pierwszym próbnym baloniku zaleją nas niemieckimi wersjami wszystkie amerykańskie wytwórnie ${ }^{31}$.

Podobny pogląd wielokrotnie pojawiał się w artykułach pisma „Filmový kurýr”, które reprezentowało przede wszystkim interesy Krajowego Związku Kinematografów w Czechach. Podstawowym argumentem krytyków była tu „jawna chęć Ameryki, by z Czechosłowacji uczynić obiekt eksploatacji, niemiecką kolonię" ${ }^{32}$. Dla właścicieli kin, którzy w roku 1930 z niechęcią obserwowali spadek zainteresowania amerykańskimi talkies, główną motywacją krytyki nie były wcale obawy przed germanizacją, ponieważ protesty przeciwko wyświetlaniu popularnych filmów niemieckich byłyby z punktu widzenia ekonomicznego nieproduktywne, ale raczej teoria, że produkcja niemieckich wersji hamuje przyjście języka czeskiego do kin, a po nim obiecywali sobie zwiększenie zysków:

Jeśli będą u nas dalej wyświetlane mówione po niemiecku filmy, nie dojdzie nigdy do produkcji czeskich wersji za granicą [...]. W takim wypadku zagranica przywoziłaby do nas filmy mówione po niemiecku, ewentualnie tylko niemieckie wersje, jak próbowali to już robić Amerykanie ${ }^{33}$.

„Národní polityka” wyraziła tę samą obawę w duchu nacjonalistycznym:

W tych niemieckich wersjach filmów amerykańskich tkwi według krajowych kręgów filmowych wielkie niebezpieczeństwo, gdyż amerykańskie wytwórnie po sukcesie niemieckich wersji w Pradze mogłyby łatwo zaliczyć nasz kraj do niemieckiej sfery swych interesów i postulat stworzenia czeskich wersji nie zostałby już przez amerykańskich producentów spełniony ${ }^{34}$.

31 Ksž [Karel Smrž], Touha každé ženy, „Lidové noviny” 1930, 6 červen, vol. 38, nr 284, s. 11.

32 Troufalost Ameriky: Pro ČSR stačí přece německá verse! „Filmový kurýr” 1930, vol. 4, nr 22 s. 2.

${ }^{33}$ Provedou kina generální stávku? Před zakazem německých mluvených filmů, „Filmový kurýr” 1930, 30 květen, vol. 4, nr 22, s. 1.

34 Předvádèní nèmeckých versí amerických filmů v pražských biografech, „Národní polityka” 1930, 24 záŕí, nr 263. 
Pierwsze artykuły o niemieckich wersjach, odzwierciedlające ich recepcję, pojawiły się w związku z projekcją filmu Prosta dusza 14 stycznia $1930 \mathrm{w}$ kinie Passage. Była to produkcja United Artists pod oryginalnym tytułem Lummox, którego niemiecka wersja dubbingowana nosiła tytuł Der Tolpatsch. To paradoksalne, że ta amerykańska produkcja była komentowana w gazetach jako pierwszy niemiecki film dźwiękowy w Pradze. Dzięki szybkości, z jaką dotarł do stolicy Czechosłowacji, dysponujemy czeskimi recenzjami, które stanowią wyjątkowe świadectwo wczesnej recepcji kulturowej dubbingu:

Praska społeczność filmowa miała wczoraj w południe w kinie Passage małą sensację: pierwszy mówiony po niemiecku film, który przywieźli United Artists. Jako że Niemcy są perfekcjonistami, jest to stuprocentowy film mówiony. A więc przede wszystkim bez muzyki i jej akompaniamentu, siedzicie jak na widowni teatralnej i słuchacie płaczliwej melodramatycznej amerykańskiej historii o niezgrabnej, serdecznej, pełnej miłości, okrutnie doświadczonej przez los służącej, która w czeskiej transkrypcji przechrzczona została na Prosta duszę, podczas gdy niemiecka wersja nazywa ją bardziej szorstko Tolpatsch, co znaczy chyba „fajtłapa”. Gra ją wspaniale nowa aktorka amerykańska Winifred Westover, chwilami przypominająca potężną panią Lehmann, chwilami delikatną i cierpiąca panią Bergner. Gra ją jednak wspaniale tak długo, póki się nie odezwie. Bowiem wskutek dodatkowego nagrania niemieckiego tekstu $\mathrm{w}$ miejsce oryginalnego angielskiego powstaje nieprzyjemna dysharmonia: ruch mówiących ust nie zgadza się ze słowem, które z nich wychodzi. Aktorka na ekranie otwiera usta, by wypowiedzieć inne sylaby i inne zestawienia głosek niż te, które dobiegają z głośników. Tak samo jest ze wszystkimi rolami $\mathrm{w}$ tym filmie. $\mathrm{W}$ dodatku głosy mają martwą, pozbawioną ducha barwę i chwilami zdają się brzmieć w naszych uszach obco, dochodzić z całkiem innej odległości niż ta, którą wyznacza iluzja obrazu. Technicznie jest to znacznie mniej doskonałe niż amerykańskie filmy dźwiękowe i mówione, które do nas do tej pory dotarly, i wydaje się, że winą za to należy obarczyć wymuszoną niemiecką synchronizację. Ten, kto sądzil, że niemiecki film mówiony może być naszemu społeczeństwu bliższy niż angielski, będzie bardzo rozczarowany: ten niemiecki jest chwilami równie niezrozumiały jak angielski dla ludzi, którzy go nie znają. Byłoby pewnie inaczej, gdyby był to niemiecki film grany przez niemieckich aktorów. A tak nie jest to ni rak, ni ryba, a już z pewnością nie jest to żaden problem polityczny. Większość zaproszonych czeskich widzów poczuła ulgę, kiedy pod koniec odezwało się trochę muzyki, przynajmniej z katarynki $[\ldots]^{35}$.

W kwietniu 1930 pojawił się w kinie Avion kolejny, prawdopodobnie dubbingowany film, tym razem brytyjski, obraz ze sławną parą komików Carlem Schenstrømem i Haroldem Madsenem, Pat i Patachon w rakietowym omnibusie. $\mathrm{W}$ następnym miesiącu miała w kinie Passage premierę pierwsza niemiecka wer-

35 Í, Ponèmčený film v Praze, „České slovo” 1930, 15 leden, nr 13, s. 5. 
sja językowa brytyjskiego filmu, Hai Tang. Jeszcze jednak w maju 1930 stale mówiło się o "niemieckich wersjach” przede wszystkim jako o filmach dubbingowanych, a nie wersjach językowych:

Trzeba bowiem odróżniać film mówiony wyprodukowany w Niemczech od amerykańskich filmów w wersji niemieckiej. [...] Owe wersje robi się na ogół metodą dodatkowej synchronizacji angielskiego filmu. Osoby na ekranie mówią innym językiem, niż ten, który odzywa się z aparatu dźwiękowego. Mniejszość filmów produkowana jest rzeczywiście tak, że w każdej z wersji grają inni aktorzy. Ameryka, uznając, że większość naszych widzów włada raczej niemieckim niż jakimkolwiek innym językiem, próbowała eksportować do nas te niemieckie wersje. Spontanicznie przeciw nim protestowano [...] dopiero wtedy, kiedy pojawiły się tu prawdziwe wersje niemieckie. Przeciwko filmom mówionym po angielsku, o ile nam wiadomo, nie odezwał się nikt. A przecież, jeśli protestuje się dopiero teraz, to protest zabrzmi raczej jako sprzeciw wobec tego, że jest to język niemiecki, a nie jako proste opowiedzenie się za filmem w wersji czeskiej ${ }^{36}$.

Bardziej drobiazgową uwagę poświęcono językowej wersji amerykańskiego filmu Victora Sjöstrema z czeskim tytułem dystrybucyjnym Touha každé ženy (Pragnienie każdej kobiety), którą przedstawiono dziennikarzom w czerwcu 1930 (premiery jednak doczekała się ona dopiero w roku następnym). Czescy dziennikarze zauważyli, że Vilma Bánky i Henry Armetta, którzy wystąpili w głównych rolach amerykańskiego oryginału i wersji niemieckiej, nie mówią po niemiecku jak native speakerzy: ,jej niemiecki jest okropny, podobnie jak niemiecki odtwórcy roli Włocha, który właściwie przez cały film mamrocze, a jego gra jest nader kiepska”37.

Pierwszą językową wersją, która stała się powodem konfliktu politycznego między dystrybutorem a czeskimi nacjonalistami, był Atlantic E. A. Duponta, wyjątkowy przykład jeśli chodzi o językowe wersje z uwagi na bogatą oprawę i duże wydatki na produkcję. Film pokazany został 15 sierpnia 1930 roku w kinie Feniks. Mówiąc dokładniej, chodziło o konflikt między firmą dystrybucyjną a właścicielem kina, Czechosłowackim Czerwonym Krzyżem, który wstrzymał projekcję i skrytykował praktykę wyświetlania niemieckojęzycznych filmów w Pradze ${ }^{38}$.

Cała kwestia wyświetlania niemieckich filmów w stolicy Czech uległa potem zaognieniu wskutek antyniemieckich demonstracji pod koniec września 1930. Te wydarzenia zostały już dokładnie opisane ${ }^{39}$, toteż nie będę im poświęcał uwagi. Skoncentruję się jedynie na wymownym szczególe z informacji, które

36 J. Trojan, Proti německému mluvícímu filmu? „Právo lidu” 1930, 31 květen.

37 Troufalost Ameriky, s. 2.

38 Zob. N. M. Wingfieldová, Film jako otázka..., s. 8.

39 Zob. ibidem; D. Moravcová, Československo, Nèmecko a evropská hnutí 19291932, Institut pro středoevropskou kulturu a politiku: Praha 2001. 
do Berlina posyłała o demonstracjach niemiecka ambasada w Pradze. Chociaż ambasador Walter W. Koch brał antyniemieckie wystąpienia w ramach tzw. Tonfilmaffäre ogólnie bardzo poważnie i był nastawiony krytycznie wobec reakcji na nie urzędów i polityków, także i on uświadamiał sobie, że negatywny stosunek do niemieckojęzycznych filmów mają jedynie wąskie, motywowane politycznie grupy mieszkańców i że szerokie kręgi czeskich widzów kinowych wprost przeciwnie, bardzo lubią niemieckie obrazy. Swoją hipotezę, że za niepokojami stoją amerykańskie biura wynajmu, które utraciły na czeskim rynku zbyt dla swych towarów, wspierał obserwacją, że „w dwu znanych praskich kinach amerykańskie filmy dźwiękowe wielokrotnie wyświetlane były przy pustej widowni”. Popularność filmów niemieckich uznał za dużo wyższą:

W Pradze mieszka mniej więcej trzydzieści tysięcy Niemców. Liczba widzów na seansach niemieckich filmów dźwiękowych pozwala wyciągnąć logiczny wniosek, że wielka część czeskiej społeczności chodzi na niemieckie filmy. Wytłumaczenie jest takie, że Czesi w większości jeśli nawet nie mówią po niemiecku, to przynajmniej język ten rozumieją, natomiast angielskiego nie znają ${ }^{40}$.

Aczkolwiek jeszcze około 23 września Masarykowski Instytut Oświaty Narodowej (Masarykův lidovýchovný ústav) skarżył się urzędom państwowym na wyświetlanie niemieckich wersji ${ }^{41}$, to ogólnie rzecz biorąc, wersje te nie należały bynajmniej do głównych tematów debaty publicznej już w okresie antyniemieckich demonstracji, gdyż uwaga skoncentrowała się na wyprodukowanych w Niemczech przebojach typu Dwoje serc $w$ takcie na trzy czwarte i Nieśmiertelny lump, które przyciągnęły do kin zaskakująco wielu czeskich widzów: „Dzisiaj jednak, kiedy wyświetla się w Pradze mówione filmy z Niemiec w wersjach niemieckich, te gazety, które rozpoczęły walkę z filmami niemieckimi, walkę o skądinąd przewidywalnym rezultacie, milczą, a nawet filmy te reklamują"42. Chociaż problem wersji niemieckich odsunęły w cień dyskusje o oryginalnych filmach mówionych z Niemiec i pierwszych takich filmach czeskich, których sukces zmienił wyobrażenia publiczności o przyszłości krajowej kinematografii, publiczne dyskusje o niemieckich wersjach żywe były przez cały rok 1930, a w osłabionym

${ }^{40}$ Deutsche Gesandtschaftsberichte aus Prag, Teil III., Hrsg. Manfred Alexander, s. 298, rękopis (zostanie opublikowany w: „Veröffentlichungen des Collegium Carolinum“, Bd. 49/III). Gdzie indziej Koch podaje, że film Dwoje serc $w$ takcie na trzy czwarte obejrzało trzysta tysięcy widzów, aczkolwiek liczbę praskich Niemców szacuje się na trzydzieści do trzydziestu pięciu tysięcy. Zob. D. Moravcová, Československo, Německo..., s. 201.

${ }^{41}$ Předvádèní nèmeckých versí amerických filmu v pražských biografech, „Národní politika" 1930, 29 záríi, nr 263.

42 Zbytečné národnostní nedorozumèní, „Filmový kurýr” 1930, 5 září, vol. 4, nr 36, s. 1 . 
stopniu przetrwały nawet do roku 1933. Niemniej aż do II wojny światowej wersje już nigdy nie skupiły na sobie uwagi prasy codziennej ani fachowej.

Poza kilkoma wyjątkami poglądy na przedstawianie oraz wartość ekonomiczną i estetyczną niemieckich wersji prezentowane w prasie codziennej i specjalistycznej były jednoznacznie negatywne. Powody takiej oceny i argumenty mogły być jednak różne. Pierwszy typ podejścia do tej kwestii mieszał filmy niemieckie z niemieckimi wersjami i razem uznawał je za narzędzie germanizacji, uważanej za największe zagrożenie dla rozwoju kultury czeskiej i jedności narodowej. Niektóre z wypowiedzi odwoływały się nawet do czasów Austro-Węgier i ówczesnej praktyki dwujęzyczności, która dobiegła kresu po powstaniu Czechosłowacji; nakazano wówczas przetłumaczenie wszystkich napisów w przestrzeni publicznej, dotyczyło to również napisów w obcojęzycznych filmach.

Drugi, bardziej wyrafinowany typ krytyki pojawiał się w pismach fachowych, których przykładem jest zwłaszcza „Filmový kurýr”; ze względu na powiązania $\mathrm{z}$ właścicielami kin, co logiczne, sprzeciwiał się on wszelkim restrykcjom, także tym dotyczącym produkcji niemieckiej. Według właścicieli kin główne niebezpieczeństwo, jakie stanowiły wersje niemieckie, polegało, o czym była już mowa, na zahamowaniu produkcji czeskich wersji językowych oraz czeskiego dubbingu tytułów amerykańskich.

Trzeci typ podejścia do kwestii, charakterystyczny dla krytyki filmowej, podkreślał estetyczną i kulturalną podrzędność wersji w ogóle i domagał się dystrybucji oryginałów:

Milieu i atmosfera nakręconego za granicą filmu nie odpowiadały mentalności narodu, w którego języku film powstawał. Poza tym, co się tyczy wersji filmów amerykańskich, zwłaszcza niemieckich, które mieliśmy okazję zobaczyć u nas, to właściwy jest im brak dobrych ról aktorskich; nie można było ich osiągnąć ze względu na kiepską ofertę aktorów grających w Ameryce w innym języku niż angielski ${ }^{43}$.

Aczkolwiek recenzje konkretnych wersji niemieckich często mówiły o obecności języka niemieckiego tonem neutralnym, niekiedy już sam wybór wersji zamiast innych możliwości stawał się powodem negatywnej oceny. Było to częste w przypadku filmów, w których występowali aktorzy niemówiący po niemiecku jak native speakerzy, na przykład Buster Keaton w niemieckojęzycznej wersji językowej filmu Salon, sypialnia i łazienka:

Ta amerykańska farsa jest nam pokazywana, nie wiadomo dlaczego, w kiepskiej wersji niemieckiej, Keaton mówi w niej całkiem amerykańskim językiem niemiec$\mathrm{kim}$ a niemieccy aktorzy są tu przeważnie nader nędzni $[\ldots]^{44}$.

43 Problem řeči a versí, „Filmový kurýr” 1931, 17 červenec, vol. 5, nr 29, s. 1.

${ }^{44}$ Dr. O. R., Nové filmy v Praze. Frigo musi mluvit, „České slovo” 1931, 6 listopad, nr 258, s. 11. 
Rozumiemy w końcu, że przy tej koncepcji filmu miejscowa filia zamiast na wersję angielską, która byłaby całkowicie niezrozumiała, zdecydowała się raczej na niemiecką, z której dialogów widz dowie się przynajmniej, o co chodzi. Dla Bustera Keatona, który zaciekle wojuje z najprostszymi niemieckimi słowami, jest to jednak niestety kolejny handicap ${ }^{45}$.

Jako przykład krytyki nakierowanej na specyfikę kulturową oryginalnego miejsca akcji, które kłóci się z niemieckimi dialogami, można podać recenzję niemieckiej wersji filmu Marius Kordy i Pagnola; obraz ten miał praską premierę 6 maja 1932 roku w kinie Adria:

Szkoda, że wyświetlana jest niemiecka wersja opracowana przez Alfreda Polgara: widzieć sceny z prawdziwej Marsylii z jej Starym Portem, z jej lokalami, przed którymi wyłożone są ostrygi, widzieć rozmaitych przedstawicieli wielobarwnej marsylskiej społeczności i słyszeć jednocześnie Alberta Bassermana i [Jakoba] Tiedtke mówiących po niemiecku to coś bezsensownego i przeszkadzającego w odbiorze filmu. Skoro są czeskie napisy, znacznie bardziej logicznym rozwiązaniem byłoby wyświetlanie oryginalnej wersji francuskiej ${ }^{46}$.

Reakcje prasy, czeskich urzędów, związków zawodowych i przedsiębiorców na wersje niemieckie można scharakteryzować jako wyjątkowy wyraz procesu oswajania filmu dźwiękowego i radzenia sobie z problemem obcych języków, którego obecność w życiu publicznym film dźwiękowy uwidocznił i uwydatnił. Ponieważ czeskie wersje zagranicznych filmów tworzą możliwą do pominięcia cząstkę przedstawianej widzom produkcji i ponieważ czeski dubbing zaczął się rozwijać z dużym opóźnieniem, to reakcje na wersje niemieckie są cennym dokumentem ukazującym, jak kultura czeska i czeski przemysł filmowy dawały sobie radę z rozszczepieniem ciała i głosu, przekładu i adaptacji kulturowej, tak charakterystycznych dla wczesnego filmu dźwiękowego jako całości.

\section{Długie trwanie w historii recepcji filmowej}

Liczby dotyczące popularności różnych produkcji narodowych jednoznacznie dowodzą, że duże wzięcie, jakim cieszył się amerykański film dźwiękowy, miało charakter krótkotrwałego boomu, jednorazowego sensacyjnego wydarzenia, będącego pewnym powierzchownym wychyleniem się, naruszeniem orientacji krajowej recepcji, która już od roku 1930 zaczęła nabierać charakteru stabilniejszego schematu preferencji: na długo pierwsze miejsce zajął w nim film czeski,

45 ksž, Frigo - svůdce žen, „Rozpravy Aventina” 1931, vol. 7, nr 9, s. 70-71.

46 F.K., Marius, „Lidové noviny” 1932, 10 květen, nr 238, s. 5. 
drugie zaś - niemiecki, a od roku 1935 amerykański. Ta hierarchia nie miała już charakteru krótkotrwałego wydarzenia, tylko dłuższego procesu toczącego się $\mathrm{w}$ wolniejszym rytmie czasowym, który zachował swoją naturę także po początkowym ekstremalnym wahnięciu, kiedy to w 1930 roku filmy czeskie okazały się aż czterokrotnie popularniejsze niż amerykańskie z tego samego roku i dwukrotnie popularniejsze od amerykańskiej produkcji z poprzedniego, „amerykańskiego” roku 1929. Tej stabilniejszej tendencji nie zmienił specjalnie nawet koniec okresu kontyngentu, który to koniec oznaczał wznowienie importu nowych produktów wytwórni zrzeszonych w Motion Pictures Association of America, co na pierwszy rzut oka mogłoby wyglądać na bodziec sprzyjający większemu zainteresowaniu czeskiej publiczności filmami hollywoodzkimi, pośród których znowu w większej mierze pojawity się wielkie produkcje o wysokim budżecie. Jednakże w roku 1935 popularność filmu amerykańskiego wzrosła tylko o 8 procent w stosunku do roku poprzedniego, z 2,3 tygodnia do 2,5. W roku następnym jeszcze lekko się zwiększyła - do 2,6 tygodnia, a w latach 1937 i 1938 znów spadła do 2,5 i 2,2 tygodnia. Wyraźnie zmienia się natomiast popularność filmu niemieckiego. Poczynając od roku 1935, zainteresowanie czeskiej publiczności produkcją niemiecką gwałtownie się obniża: najpierw spada o 30 procent w roku 1935 (2,1 tygodnia), potem po niewielkim zwiększeniu w roku następnym (2,3 tygodnia) znowu mocno zniżkowała, do 1,8 tygodnia (1937) i 1,5 tygodnia (1938). Produkcja czeska trwale utrzymuje pierwszą pozycję, chociaż i w jej wypadku dochodzi do lekkiego spadku - do 4 tygodni (1935), 3,5 tygodnia (1936), 3,9 tygodnia (1937) i 3,6 tygodnia $(1938)^{47}$. Powodów zmniejszenia popularności filmu niemieckiego po roku 1934 w niniejszym studium, dotyczącym głównie wczesnego okresu dźwiękowego, nie mogę w pełni ukazać, niemniej można sądzić, iż znaczną rolę odegrały zmiany w samym niemieckim przemyśle filmowym, które na zagranicznym rynku nie znalazły odzwierciedlania zaraz po dojściu nazistów do władzy, ale dopiero kilka lat później. Kolejnym powodem skracania się czasu wyświetlania w kinach premierowych nie tylko w wypadku niemieckich, ale i czeskich filmów, mógł być koniec kontyngentu, kiedy to ogólnie wyższa liczba filmów (zwłaszcza amerykańskich, o które w poprzednich latach widownia była częściowo zubożona) mogła wywierać pewien nacisk, podpowiadając szybszą zmianę repertuaru.

Taką samą krzywą rozwojową - na początku dwa silne wahnięcia (wyjątkowa popularność filmu amerykańskiego, a potem czeskiego), następnie zaś stabi-

${ }^{47} \mathrm{~W}$ tych dodatkowych wyliczeniach ograniczam się do okresu przed początkiem II wojny światowej i jako źródła używam roczników Havelki: Čs, filmové hospodařství II.-V., Knihovna filmového kurýru: Praha 1935-1939. Od roku 1936 opieram się na własnych obliczeniach Havelki, który określa liczbę tygodni okresu wyświetlania premierowego, jeśli chodzi o poszczególne produkcje narodowe. Odejmuję od nich dane dotyczące wersji. 
lizacja hierarchii: film czeski/niemiecki/amerykański - mamy w badanym okresie (1929-1934), jeśli chodzi o największe przeboje kasowe. W pierwszym roku $\mathrm{z}$ amerykańskimi filmami nie konkurowała żadna inna dźwiękowa produkcja narodowa, ale ich wielką popularność mierzyć można przez porównanie $\mathrm{z}$ frekwencją na czeskich filmach niemych z tego samego okresu (przeciętnie 3,1 tygodnia). W następnych latach filmy amerykańskie dostawały się na najwyższe miejsca „list przebojów" jedynie wyjątkowo.

Jak możemy zinterpretować relatywne powodzenie "niemieckich wersji”? „Niemieckie wersje” były przede wszystkim znacznie mniej popularne niż niemieckie filmy w całym tego słowa znaczeniu, a więc produkcje oznaczane i rozumiane jako niemieckie - średnio o 25 procent. Na podstawie tych danych można z dużą dozą pewności stwierdzić, że kalkulacje amerykańskich producentów i dystrybutorów, którzy podobno zastanawiali się nad włączeniem Czechosłowacji do grupy rynków niemieckojęzycznych, nie odzwierciedlały rzeczywistych preferencji krajowych widzów. Większa popularność filmów niemieckich, a nawet i amerykańskich w oczywisty sposób dowodzi, że po pierwsze, publiczność stawiała estetyczne i kulturalne wartości filmu wyżej niż samą zrozumiałość (którą zapewniały wersje zmieniające język angielski na niemiecki), po drugie zaś, że filmy niemieckie tworzyły najpopularniejszą grupę produkcji importowanych nie tylko z powodu znajomości języka, ale przede wszystkim z powodu bliskości kulturowej.Jeśli ustalimy lokalne kryterium przeboju, uznając, że jest nim 8 tygodni wyświetlania w kinach premierowych (ta liczba wydaje się najwłaściwsza dla czeskiego rynku filmowego pierwszej połowy lat trzydziestych), jedyną wersją niemiecką w grupie hitów będzie Nietoperz Lamača, który od innych wersji różni się przede wszystkim tym, że wśród odtwórców znalazła się czeska gwiazda Anny Ondráková.

Także w przypadku filmów amerykańskich możemy stwierdzić, że po początkowym krótkotrwałym boomie w drugiej połowie 1929 roku, w latach 1930 1934 hollywoodzkie produkty dostały się do grupy przebojów już tylko trzykrotnie (wobec 27 hitów czeskich i 10 niemieckich), mianowicie w latach 1931-1932 amerykańskimi hitami były Parada miłości, Uśmiechnięty porucznik i Na zachodzie bez zmian. Wszystkie te filmy są w rzucający się w oczy sposób „europejskie” czy wręcz „niemieckie”, już to ze względu na swój styl, już to ze względu na pomysł scenariuszowy, gatunek czy gwiazdy w obsadzie. Uśmiechnięty porucznik i Parada miłości to filmowa operetka i komedia romantyczna, oba obrazy są dziełem reżysera Ernsta Lubitscha, w obu w roli głównej występuje Maurice Chavalier. Natomiast Na zachodzie bez zmian to adaptacja powieści Ericha Marii Remerque’a, której akcja toczy się w niemieckim miasteczku i na niemiecko-francuskim froncie podczas I wojny światowej. Nie były to więc westerny, horrory, musicale ani rewie, ale filmy typu, do którego czeski widz był przyzwyczajony dzięki produkcjom europejskim, przede wszystkim niemieckim. Główną część zagranicznych przebojów w czeskich kinach, tworzoną przez filmy niemieckie, takie jak Dwoje 
serc $w$ takcie na trzy czwarte, Front zachodni 1918, Prywatna sekretarka czy Kongres tańczy, można znaleźć również w zestawieniach najpopularniejszych filmów na rynku niemieckim tego okresu, które opracował Joseph Garncarz ${ }^{48}$. Czołowa pozycja czeskiej produkcji dźwiękowej z lat 1930-1934 w zestawie przebojów jest jeszcze wyraźniejsza niż w liczbach wziętych z ogólnego obrazu produkcji narodowej. Czeskich hitów pojawiło się wtedy trzy razy więcej niż amerykańskich, przy czym bezkonkurencyjną supergwiazdą praskich kin stał się Vlasta Burian, filmy z jego udziałem zajęly pierwsze miejsca w latach 1930-1933.

Wydaje się więc, że rolę filmu amerykańskiego w czeskich kinach w okresie wczesnego filmu dźwiękowego trzeba w świetle popularności oceniać inaczej niż dotychczas i że znaczenie produkcji niemieckiej dla wykształcenia się obrazu filmu dźwiękowego w Czechosłowacji było większe niż może wydawać się na podstawie danych o przedstawianych filmach i dystrybucji. „Wersje niemieckie”, badane dla porównania, wskazują na to, że większa popularność filmów niemieckich nie była spowodowana większą zrozumiałością języka, tylko raczej bliskością kulturową opowiadanych historii oraz ikonografii niemieckiej kultury popularnej, której oswajanie przez czeską publiczność trwało dłużej i w biegnącym wolniej czasie historycznym niż w dobie nowości technicznych i sensacji, oferowanych przez amerykańskie talkies z drugiej połowy roku 1929. Płaszczyzna społeczna mentalności odznacza się zdecydowanie wolniejszym czasem historycznym ${ }^{49}$ : w tej płaszczyźnie Czechy i Morawy były stale częścią austriacko-niemieckich obszarów wpływu, co przejawiało się - niezależnie od znanych demonstracji przeciw filmom niemieckojęzycznym - wysoką frekwencją na seansach niemieckich obrazów dźwiękowych, która dla ówczesnych publicystów filmowych była rzeczą niezrozumiałą.

Dla głębszego zrozumienia historycznych prawideł recepcji w historii czeskiej kinematografii trzeba jednak przeprowadzić dalsze badania, uwzględniając szerszą gamę źródeł i danych niż ta, którą można było wykorzystać na potrzeby niniejszego studium. Dotychczasowe rezultaty prezentowanych tu badań pozostawiają bowiem wiele zagadnień otwartymi. Gdybyśmy punkt widzenia popularności, czyli popytu, skonfrontowali wtórnie z danymi o podaży, to natrafimy na pytanie, jakie właściwie były stosunki przyczynowo-skutkowe między wielkością podaży i popytu, dlaczego dystrybutorzy nie reagowali prężniej na preferencje widzów. Czy umożliwiały taką sytuacje konkretne praktyki filii amerykańskich w Pradze, które nawet na rynku czeskim ${ }^{50}$ umiały filmom

48 J. Garncarz, publikacja w niniejszym tomie, s. 75-76.

49 Por. analizy różnych przejawów tego zjawiska w głównych narodowych kulturach filmowych Europy w: P. Sorlin, European Cinemas, European Societies, 1939-1990, Routledge: London 1991.

50 W kwestii problemu braku terminów wyświetlania i wielkiej przewagi dystrybucyjnych propozycji w stosunku do realnych potrzeb, z którym zmagali się importerzy od 
hollywoodzkim zapewnić ilościowe preferencje, aczkolwiek produkty niemieckie były bardziej pożądane? Do tych agresywnych praktyk, mających za cel wyeliminowanie konkurencji nawet za cenę obniżenia zysków, należało przede wszystkim tzw. block-booking, przymusowe dystrybuowanie filmów w całych zestawach za bardzo niską cenę. Zestaw zwykle zawierał jeden „pewny” przebój oraz grupę mniej atrakcyjnych obrazów, przy czym mogło go tworzyć 10, 15, ale i 40 tytułów. Aczkolwiek ten zabieg znali już od początku XX wieku również producenci i dystrybutorzy europejscy, tylko Amerykanie potrafili go efektywnie wykorzystać, ponieważ produkowali wystarczająco dużo filmów i dzięki rynkowi krajowemu wydatki zwracały im się bez względu na dystrybucję na rynkach zewnętrznych, mogli więc za granicą oferować filmy za wyjątkowo niskie ceny. We Francji owa taktyka prowadziła do wypierania produkcji krajowej, na co miejscowi producenci skarżyli się w roku 1929 ambasadzie USA. Z Amerykanami, ich zdaniem, nie dało się konkurować, ponieważ „oferowali filmy za dowolną cenę, nawet taką, która nie pokrywała kosztów eksploatacji kopii, tylko po to, żeby w ten sposób zablokować naszą drogę do kin" ${ }^{51}$. Związaną z tym zabiegiem inną strategią amerykańskich producentów i dystrybutorów było tzw. blind-booking, przymusowe dystrybuowanie filmów, których właściciele kin nie mogli jeszcze widzieć ani uzyskać informacji o ich treści i jakości, ponieważ często nie były jeszcze nawet dokończone. Obu metod zakazało prawo brytyjskie, mianowicie Cinematograph Films Act of 1927. W samych Stanach Zjednoczonych w tym samym czasie zaczęly one być przedmiotem sporów prawnych, ale na przykład we Francji pozostały legalne do roku $1934^{52}$. W Czechosłowacji

drugiej połowy lat 20. do wprowadzenia kontyngentu, por. G. Heiss, I. Klimeš, Kulturní primysl a polityka..., s. 310.

${ }_{51}$ Cyt. za: J. Ulff-Møller, Hollywood's „Foreign War”: The Effect of National Commercial Policy on the Emergence of American Film Hegemony in France, 1920-1929, [w:] „Film Europe" and "Film America". Cinema, Commerce and Cultural Exchange 1920-1939, eds. A. Higson, R. Maltby, Exeter University Press: Exeter 1999, s. 202.

${ }_{52}$ Za zwrócenie mi uwagi na możliwość wpływu tych amerykańskich metod dystrybucyjnych podziękowania zechce przyjąć Ivan Klimeš. W kwestii amerykańskich zmagań prawnych o block-booking zob. J. A. Aberdeen, Block Booking Battle in Congress. W sieci: http:///www.cobbles.com/simpp_archive/blockbook_neely,htm. W kwestii zakazu block-booking przez Cinematograph Films Act of 1927 por. „British Official Publications Collaborative Reader Information Service". W sieci: http://www.bopcris. ac.uk/cgi-bin/sisplayrec.pl?search text=Cinematograph+Films+Act\&record=/bopall/ ref8001.html. W kwestii współczesnego omawianym zjawiskom czeskiego opisu tego aktu prawnego i zakazu blind-booking por. „uzasadnienie” propozycji prawa filmowego z roku 1929, w: Osnova zákona k podpoře domácí filmové výroby, red. I. Klimeš, „Iluminace" 1997, vol. 9, nr 4, s. 159. W kwestii sporów francusko-amerykańskich o block-booking zob. J. Ulff-Møller, Hollywood's „Foreign War”..., s. 187-188. 
wprawdzie w wytycznych Ministerstwa Handlu z roku 1931 w kwestii praktyki importu znajdował się zakaz „wiązania programów” i „sprzedaży na ślepo”, ale jak w związku z tymi zakazami zwrócił uwagę w 1935 Jiř́i Havelka, przepisów nie przestrzegano lub je obchodzono ${ }^{53}$.

Gdyby udowodniono znaczący wpływ tych strategii dystrybucyjnych na długość wyświetlania filmów amerykańskich w praskich kinach, hipoteza o reaInie mniejszej popularności, a więc i mniejszym kulturowym wpływie hollywoodzkich produktów w stosunku do filmów niemieckich i czeskich znalazłaby mocniejsze potwierdzenie. Pojawia się kolejne pytanie: jaki był właściwie skutek bojkotu czeskiego rynku ze strony wielkich producentów amerykańskich w okresie kontyngentu (1932-1934), który to okres poprzedziło gwałtowne obniżenie zainteresowania widzów filmami z USA, i czy Amerykanie pod jego koniec wynegocjowali jakieś szczególne warunki, które nie wynikają z rozporządzeń? Czy ten bojkot i czasowy spadek podaży amerykańskiej produkcji miał za cel wywołanie przesytu czeskiej publiczności towarem niemieckim i czy był powodem odrodzenia się popytu na wyroby z Hollywood po roku 1934? Te pytania musimy tu jednak pozostawić bez odpowiedzi, ponieważ kwestię tę można by wyjaśnić jedynie na podstawie dalszych badań w archiwach producentów amerykańskich i w źródłach dokumentujących funkcjonowanie lokalnej dystrybucji i prezentacji filmów.

Tabela 1. Długometrażowe fabularne filmy dźwiękowe w czeskiej dystrybucji (na podstawie danych z cenzury)

\begin{tabular}{|l|c|c|c|c|c|c|}
\hline \multicolumn{1}{|c|}{ Kraj } & 1929 & 1930 & 1931 & 1932 & 1933 & 1934 \\
\hline Czechosłowacja & - & 8 & 23 & 24 & 44 & 37 \\
\hline Niemcy & - & 74 & 151 & 82 & 87 & 74 \\
\hline USA & 48 & 149 & 145 & 36 & 19 & 24 \\
\hline Francja & - & 10 & 20 & 21 & 29 & 22 \\
\hline
\end{tabular}

53 Wytyczne wymagały przestrzegania rozporządzenia Ministerstwa Przemysłu, Handlu i Rzemiosła (MPOŽ) z 9 listopada 1931 roku, nr 129.606/31, które uzależniało import dźwiękowych filmów fabularnych od wydania pozwolenia. Zakaz „wiązania programów” i „sprzedaży na ślepo” pokazuje, że praktyki te w poprzednich latach były na czeskim rynku typowe. Tekst rozporządzenia zob. „Věstník ministerstwa průmyslu, obchodu a živností”, 1931, rocznik 12, s. 686. Por. J. Havelka, Čs, filmové hospodařství I., s. 4. Por. też propozycję wytycznych w kwestii udzielania pozwoleń na import, w: Archiv Ministerstva zahraničních věcí, III. sekce 1918-1938, k. 408, č.j. 139497/31. 
Tabela 2. pokazuje:

1) liczbę fabularnych filmów dźwiękowych danej proweniencji narodowej przedstawianych w praskich kinach premierowych (osobno podane są dane o niemieckich wersjach filmów nieniemieckich);

2) średni czas wyświetlania w kinach premierowych (w tygodniach zaokrąglonych do jednego miejsca po przecinku) ${ }^{54}$.

Tabela 2. Popularność pełnometrażowych dźwiękowych filmów fabularnych według proweniencji narodowej

\begin{tabular}{|l|c|c|c|c|c|c|c|c|c|c|c|c|}
\hline & \multicolumn{2}{|c|}{1929} & \multicolumn{2}{|c|}{1930} & \multicolumn{2}{c|}{1931} & \multicolumn{2}{c|}{1932} & \multicolumn{2}{c|}{1933} & \multicolumn{2}{c|}{1934} \\
\hline Czechosłowacja & - & - & 5 & 9,6 & 18 & 6,2 & 3 & 7 & 29 & 5,1 & 32 & 5,1 \\
\hline Niemcy & - & - & 36 & 3,4 & 106 & 2,7 & 121 & 2,9 & 73 & 3,9 & 81 & 3 \\
\hline USA & 20 & 4,8 & 136 & 2,5 & 116 & 2,1 & 45 & 2 & 24 & 2,7 & 24 & 2,3 \\
\hline Francja & - & - & 14 & 2 & 11 & 1,5 & 13 & 2,8 & 24 & 3 & 26 & 33 \\
\hline Wersje niemieckie & - & - & 7 & 2 & 21 & 2 & 15 & 2,4 & 4 & - & 3 & - \\
\hline
\end{tabular}

\begin{tabular}{|l|c|}
\hline \multicolumn{2}{|c|}{ Średnia popularność w latach $1929(1930)-1934$} \\
\hline 1. Czechosłowacja & 6,6 \\
\hline 2. Niemcy & 3,2 \\
\hline 3. USA & 2,7 \\
\hline 4. Francja & 2,5 \\
\hline 5. Wersje niemieckie & 2,4 \\
\hline
\end{tabular}

${ }^{54}$ Jeśli liczba filmów w danej kategorii jest niższa niż pięć, nie podaję średniego czasu wyświetlania, ponieważ przy tak niskiej liczbie dane o średnim czasie mogłyby być mylące. W liczbach filmów amerykańskich nie są uwzględnione wersje niemieckie, hiszpańskie i włoskie filmów z USA; to samo dotyczy filmów francuskich; w ocenie popularności filmów czeskich nie są uwzględniane niemieckie wersje produkcji z CSR, amerykańskie wersje z czeskimi mówionymi wstawkami ani synchronizowane wersje filmów niemych, zostały natomiast uwzględnione czeskie wersje językowe (nie wersje dubbingowane) filmów zagranicznych. Do niemieckich wersji filmów zagranicznych nie włączałem tytułów, które Havelka (Čs. filmové hospodařství I) oznacza jako niemieckie wersje austriackich i szwajcarskich filmów ani niemieckich wersji zagranicznych obrazów dokumentalnych. Datowanie filmów nie opiera się, jak podstawowe podsumowania Havelki, na dacie podanej przez cenzurę, lecz na dacie premiery (według spisu premier na s. 177-198). 
Tabela 3. Spis najpopularniejszych dźwiękowych filmów fabularnych granych w praskich kinach w latach 1929-193455

\begin{tabular}{|c|c|c|c|}
\hline Rok & Film & Kraj & $\begin{array}{l}\text { Liczba } \\
\text { tygodni }\end{array}$ \\
\hline \multirow[t]{5}{*}{1929} & Śpiewajacy błazen (Singing Fool; Lloyd Bacon, 1928) & USA & 12 \\
\hline & $\begin{array}{l}\text { Białe cienie na morzach południowych (czes. Bilé stiny, } \\
\text { White Shadows in the South Seas; W.S. Van Dyke, } \\
\text { 1928) }\end{array}$ & USA & 12 \\
\hline & $\begin{array}{l}\text { Cztery diably (czes. Čtyři d'ablové, Four Devils; Frie- } \\
\text { drich Murnau, 1928-1929, udźwiękowiona wersja) }\end{array}$ & USA & 11 \\
\hline & $\begin{array}{l}\text { Statek komediantów (czes. Lod'komediantů, } \\
\text { Show Boat; Harry A. Pollard, Arch Heath, 1929) }\end{array}$ & USA & 9 \\
\hline & $\begin{array}{l}\text { Arka Noego (czes. Archa Noemova, Noah's Ark; Mi- } \\
\text { chael Curtiz, Darry F. Zanuck, 1928) }\end{array}$ & USA & 8 \\
\hline \multirow[t]{8}{*}{1930} & $\begin{array}{l}\text { Fatszywy marszałek (czes. C. a k. polní maršálek; } \\
\text { Karel Lamač, 1930) }\end{array}$ & $\begin{array}{l}\text { Czecho- } \\
\text { słowacja }\end{array}$ & 22 \\
\hline & $\begin{array}{l}\text { Dwoje serc w takcie na trzy czwarte (czes. Dvě srdce ve } \\
\text { 3/4 taktu, Zwei Herzen im Dreiviertel Takt; Géza von } \\
\text { Bolváry, 1930) }\end{array}$ & Niemcy & 17 \\
\hline & $\begin{array}{l}\text { Parada miłości (czes. Přehlídka lásky, The Love Para- } \\
\text { de; Ernst Lubitsch, 1929) }\end{array}$ & USA & 12 \\
\hline & $\begin{array}{l}\text { Szewskie święto (czes. Fidlovačka; Svatopluk Inne- } \\
\text { mann, 1930) }\end{array}$ & $\begin{array}{l}\text { Czecho- } \\
\text { słowacja }\end{array}$ & 12 \\
\hline & $\begin{array}{l}\text { Nieśmiertelny lump (czes. Nesmrtelnýlump, Der } \\
\text { Unsterblische Lump; Gustav Ucicky, Joe May, 1930) }\end{array}$ & Niemcy & 9 \\
\hline & $\begin{array}{l}\text { Na zachodzie bez zmian (czes. Na západní frontě } \\
\text { klid, All Quiet on the Western Front; Levis Milestone, } \\
\text { 1930) }\end{array}$ & USA & 9 \\
\hline & $\begin{array}{l}\text { Front zachodni } 1918 \text { (czes. Na západní frontě 1918, } \\
\text { Westfront 1918, Georg Wilhelm Pabst, 1930) }\end{array}$ & Niemcy & 8 \\
\hline & $\begin{array}{l}\text { Koniec pieśni (czes. Dozněla píseň, Das Lied ist aus; } \\
\text { Géza von Bolváry, 1930) }\end{array}$ & Niemcy & 8 \\
\hline
\end{tabular}

55 W każdym roku wybieram tytuły, które osiągnęły przynajmniej osiem tygodni wyświetlania w kinach premierowych. Jeśli liczba tygodni jest taka sama, o kolejności decyduje to, który tytuł miał praską premierę wcześniej. Podając czeskie przekłady, używam wyłącznie tytułów podawanych przez dystrybutorów. Oznaczenia „n” i „f” wskazują, że chodzi odpowiednio o wersję niemiecką i francuską. 


\begin{tabular}{|c|c|c|c|}
\hline \multirow[t]{9}{*}{1931} & $\begin{array}{l}\text { Tego pan nie zna, panie Hadimrška (czes. To neznáte } \\
\text { Hadimršku; Karel Lamač i Martin Frič, 1931) }\end{array}$ & $\begin{array}{l}\text { Czecho- } \\
\text { słowacja }\end{array}$ & 14 \\
\hline & $\begin{array}{l}\text { Uśmiechnięty porucznik (czes. Kouzlo valčíku, The } \\
\text { Smiling Lieutnant; Ernst Lubitsch, 1931) }\end{array}$ & USA & 12 \\
\hline & $\begin{array}{l}\text { Na spalonym (czes. Muži v offsidu; Svatopluk Inne- } \\
\text { mann, 1931) }\end{array}$ & $\begin{array}{l}\text { Czecho- } \\
\text { słowacja }\end{array}$ & 12 \\
\hline & $\begin{array}{l}\text { Prywatna sekretarka (czes. Privátní sekretárka, Die } \\
\text { Privatsekretärin; Wilhelm Thiele, 1931) }\end{array}$ & Niemcy & 9 \\
\hline & $\begin{array}{l}\text { Ulubieniec pułku (czes. Miláček pluku; Emil Artur } \\
\text { Longen, 1931) }\end{array}$ & $\begin{array}{l}\text { Czecho- } \\
\text { słowacja }\end{array}$ & 9 \\
\hline & $\begin{array}{l}\text { Trzecia kompania (czes. Třetí rota; Svatopluk Inne- } \\
\text { mann, 1931) }\end{array}$ & $\begin{array}{l}\text { Czecho- } \\
\text { słowacja }\end{array}$ & 9 \\
\hline & $\begin{array}{l}\text { On i jego siostra (czes. On a jeho sestra; Karel Lamač } \\
\text { i Martin Frič, 1931) }\end{array}$ & $\begin{array}{l}\text { Czecho- } \\
\text { słowacja }\end{array}$ & 8 \\
\hline & $\begin{array}{l}\text { Ostatni cygan (czes. Poslední bohém; Svatopluk Inne- } \\
\text { mann, 1931) }\end{array}$ & $\begin{array}{l}\text { Czecho- } \\
\text { słowacja }\end{array}$ & 8 \\
\hline & $\begin{array}{l}\text { Kongres tańczy (czes. Kongres tančí, Der Kongress } \\
\text { tanzt; Erik Charell, 1931) }\end{array}$ & Niemcy & 8 \\
\hline \multirow[t]{10}{*}{1932} & $\begin{array}{l}\text { Lelíček na ustugach Sherlocka Holmesa (czes. Lelíček } \\
\text { ve službách Sherlocka Holmesa; Karel Lamač, 1932) }\end{array}$ & $\begin{array}{l}\text { Czecho- } \\
\text { słowacja }\end{array}$ & 17 \\
\hline & $\begin{array}{l}\text { Szynkarka w gospodzie „Pod Szalonym Pięknem” } \\
\text { (czes. Šenkýrḱka „U divoké krásy”; Svatopluk Inne- } \\
\text { mann, 1932) }\end{array}$ & $\begin{array}{l}\text { Czecho- } \\
\text { słowacja }\end{array}$ & 12 \\
\hline & $\begin{array}{l}\text { Piosenkarz (czes. Písničkář; Svatopluk Innemann, } \\
\text { 1932) }\end{array}$ & $\begin{array}{l}\text { Czecho- } \\
\text { słowacja }\end{array}$ & 12 \\
\hline & $\begin{array}{l}\text { Strzelec Anton Špelec (czes. Anton Špelec, ostrostřelec; } \\
\text { Martin Frič, 1932) }\end{array}$ & $\begin{array}{l}\text { Czecho- } \\
\text { słowacja }\end{array}$ & 11 \\
\hline & $\begin{array}{l}\text { Przed matura (czes. Před maturitou; Vladislav } \\
\text { Vančura, 1932) }\end{array}$ & $\begin{array}{l}\text { Czecho- } \\
\text { słowacja }\end{array}$ & 10 \\
\hline & Grabarz (czes. Funebrák; Karel Lamač, 1932) & $\begin{array}{l}\text { Czecho- } \\
\text { słowacja }\end{array}$ & 9 \\
\hline & $\begin{array}{l}\text { Nietoperz (czes. Netopýr, La Chauve-souris; Pierre } \\
\text { Billon, Karel Lamač, 1931) }\end{array}$ & Francja (n) & 8 \\
\hline & $\begin{array}{l}\text { Biuro matrymonialne (czes. Sňatková kancelárí; Sva- } \\
\text { topluk Innemann, 1932) }\end{array}$ & $\begin{array}{l}\text { Czecho- } \\
\text { słowacja }\end{array}$ & 8 \\
\hline & $\begin{array}{l}\text { Muszkieterowie z Malej Strany (czes. Malostranští } \\
\text { mušketýři; Svatopluk Innemann, 1932) }\end{array}$ & $\begin{array}{l}\text { Czecho- } \\
\text { Słowacja }\end{array}$ & 8 \\
\hline & Quick (Robert Siodmak, 1932) & Niemcy & 8 \\
\hline
\end{tabular}




\begin{tabular}{|c|c|c|c|}
\hline \multirow[t]{5}{*}{$\begin{array}{l}1932 \\
\text { cd. }\end{array}$} & $\begin{array}{l}\text { Modry Dunaj (czes. Cikánská simfonie, The Blue } \\
\text { Danube; Herbert Wilcox, 1932) }\end{array}$ & $\begin{array}{l}\text { Wielka } \\
\text { Brytania } \\
\quad \text { (f) }\end{array}$ & 8 \\
\hline & Idealny belfer (czes. Kantor Ideál; Martin Frič, 1932) & $\begin{array}{l}\text { Czecho- } \\
\text { słowacja }\end{array}$ & 8 \\
\hline & $\begin{array}{l}\text { Pod cudza flaga (czes. Pod cizí vlajkou, Unter falscher } \\
\text { Flagge; Johannes Meyer, 1932) }\end{array}$ & Niemcy & 8 \\
\hline & Fantomas (Fantômas; Pál Fejös, 1932) & Francja & 8 \\
\hline & $\begin{array}{l}\text { Patrioci z zakatka (czes. Zapadlí vlastenci; Miroslav } \\
\text { J. Krňanský, 1932) }\end{array}$ & $\begin{array}{l}\text { Czecho- } \\
\text { słowacja }\end{array}$ & 8 \\
\hline \multirow[t]{8}{*}{1933} & $\begin{array}{l}\text { Adiutant Jego Wysokości (czes. Pobočník jeho výsosti; } \\
\text { Martin Frič, 1933) }\end{array}$ & $\begin{array}{l}\text { Czecho- } \\
\text { słowacja }\end{array}$ & 15 \\
\hline & $\begin{array}{l}\text { Madla z cegielni (czes. Madla z cihelny; Vladimír } \\
\text { Slavínský, 1933) }\end{array}$ & $\begin{array}{l}\text { Czecho- } \\
\text { słowacja }\end{array}$ & 10 \\
\hline & $\begin{array}{l}\text { Okienko (czes. Okénko; Vladimír Slavínský, UFA, } \\
\text { 1933) }\end{array}$ & $\begin{array}{l}\text { Czecho- } \\
\text { słowacja }\end{array}$ & 9 \\
\hline & $\begin{array}{l}\text { Bezdomni (czes. Cesta do života, Putiovka w żyzń; } \\
\text { Nikołaj Ekk, 1931) }\end{array}$ & ZSRR & 8 \\
\hline & $\begin{array}{l}\text { Pieśń dla ciebie (czes. Píseñ pro tebe, Ein Lied für dich; } \\
\text { Joe May, 1933) }\end{array}$ & Niemcy & 8 \\
\hline & $\begin{array}{l}\text { Restauracja „U świętego Antosia” (czes. U svatého } \\
\text { Antonička; Svatopluk Innemann, 1933) }\end{array}$ & $\begin{array}{l}\text { Czecho- } \\
\text { słowacja }\end{array}$ & 8 \\
\hline & $\begin{array}{l}\text { Prywatne życie Henryka VIII (czes. Šest žen Jindři- } \\
\text { cha VIII., The Private Life of Henry VIII; Alexander } \\
\text { Korda, 1933) }\end{array}$ & $\begin{array}{l}\text { Wielka } \\
\text { Brytania }\end{array}$ & 8 \\
\hline & $\begin{array}{l}\text { Chatka z piernika (czes. Perníková chaloupka; } \\
\text { Oldřich Kmínek) }\end{array}$ & $\begin{array}{l}\text { Czecho- } \\
\text { słowacja }\end{array}$ & 8 \\
\hline \multirow[t]{5}{*}{1934} & $\begin{array}{l}\text { Złota Katarzyna (czes. Zlatá Kateřina; Vladimír } \\
\text { Slavínský, 1934) }\end{array}$ & $\begin{array}{l}\text { Czecho- } \\
\text { słowacja }\end{array}$ & 12 \\
\hline & $\begin{array}{l}\text { Rozpustna Csibi (czes. Rozpustilá Čibi, Csibi, der } \\
\text { Fratz/Früchtchen; Max Neufeld, Richard Eichberg, } \\
\text { 1934) }\end{array}$ & Austria & 11 \\
\hline & $\begin{array}{l}\text { Dopóki masz mamę (czes. Dokud máš maminku; Jan } \\
\text { Sviták, 1934) }\end{array}$ & $\begin{array}{l}\text { Czecho- } \\
\text { słowacja }\end{array}$ & 9 \\
\hline & $\begin{array}{l}\text { Moskiewskie noce (czes. Moskevské noci, Les Nuits } \\
\text { moscovites; Alexis Granovsky, 1934) }\end{array}$ & Francja & 9 \\
\hline & $\begin{array}{l}\text { Moje serce tęskni za toba (czes. Mé srdce touží po lásce, } \\
\text { Mein Herz ruft nach dir; Carmine Gallone, 1934) }\end{array}$ & Niemcy & 8 \\
\hline
\end{tabular}




\begin{tabular}{|l|l|c|c|}
\hline & $\begin{array}{l}\text { Bitwa (czes. Bitva, La Bataille; Nicolas Farkas, Vik- } \\
\text { tor Tourjansky, 1988) }\end{array}$ & Francja & 8 \\
\cline { 2 - 4 } & $\begin{array}{l}\text { Życie żotnierskie - wesołe życie (czes. Život vojenský - } \\
\text { Život veselý; Jan Sviták, 1934) }\end{array}$ & $\begin{array}{c}\text { Czecho- } \\
\text { słowacja }\end{array}$ & 8 \\
\cline { 2 - 4 } & $\begin{array}{l}\text { Nie denerwować dziadunia (czes. Nezlobte dědečka; } \\
\text { Karel Lamač, 1934) }\end{array}$ & $\begin{array}{l}\text { Czecho- } \\
\text { słowacja }\end{array}$ & 8 \\
\hline
\end{tabular}

Wykaz niemieckich wersji, wyświetlanych w praskich kinach w latach 1930-193456

\section{0}

Prostá duše (Der Tolpatsch - Lummox; Herbert Brenon, 1930) dubbing, USA, Passage, 14.01.1930.

Pat a Patachon $v$ raketovém omnibusu (Pat und Patachon im Raketenomnibus - The Rocket Bus / Alf's Carpet; W. P. Kellino, 1929) dubbing [?], Wielka Brytania, Avion 2; 25.04.1930.

Hai Tang (Hai-Tang. Der Weg zur Schande; Richard Eichberg, 1929/1930 - The Flame of Love; Richard Eichberg i Walter Summers, 1929/1930) MW, Wielka Brytania, Passage 3; 9.05.1930.

Atlantic (Atlantic; A. Dupont, 1929 - Atlantic; A. Dupont, 1929) MW, Wielka Brytania; Fénix 5; 15.08.1930.

Kibic (Der Kibitzer - The Kibitzer; Edward Sloman, 1930) dubbing [?], USA; Kotva 1; 29.08.1930.

Sensace divadla Tivoli (Sensation des Theaters Tivoli - Gold Diggers of Broadway; Roy del Ruth, 1929) dubbing [?], USA; Passage 1; 3.10.1930.

Moc a marnost milionu (Millionen sind nicht alles - Such Men Are Dangerous; Kenneth Hawks, 1930) częściowo MW [?], częściowo „wersja międzynarodowa”, USA, Fénix $1 ; 17.10 .1930$.

56 Wykaz ten został sporządzony na podstawie porównania szeregu źródeł, m.in. podsumowań Havelki, „Rubryki filmowej” „Biuletynu Ministerstwa Spraw Wewnętrznych”, baz danych American Film Institute, filmograficznych baz danych o wersjach językowych, które opracował niemiecki historyk filmu Hans-Michael Bock (dziękuję mu w tym miejscu za pomoc), a także recenzji i reklam w czeskiej prasie z intersującego mnie okresu. Tytuły są ułożone według dat praskich premier; przy każdym wymieniony jest najpierw czeski tytuł dystrybucyjny, potem w nawiasie: tytuł wersji niemieckiej, reżyser wersji niemieckiej (jeśli chodzi o wersję językową), tytuł oryginalny, reżyser wersji oryginalnej, rok produkcji, za nawiasem: typ wersji (MW czyli wersja językowa albo dubbing, ewentualnie „tylko niemiecka wersja”, co oznacza, że chodzi o niemiecki film nakręcony tylko po niemiecku), kraj produkcji, praskie kino premierowe, liczba tygodni wyświetlania w premierowym kinie, data premiery. Jeśli brakuje informacji o długości premierowego wyświetlania, oznacza to, że w podsumowaniach Havelki film nie został wspomniany; znak zapytania wskazuje na niepewność dotyczącą typu wersji (czy szło o dubbing, czy MW, czy o niemiecki film wyprodukowany tylko w wersji niemieckiej). 


\section{1}

Nedèle života (Sonntag des Lebens; Leo Mittler, 1930 - The Devil's Holiday; Edmund Goulding, 1930) MW, USA; Olympic 1; 13.02.1931.

Touha každé ženy (Die Sehnsucht jeder Frau; Victor Sjöström, 1930 - A Lady to Love;

Victor Sjöström, 1930) MW, USA; Kotva 1; 6.03.1931.

Olympia (Olympia; Jacques Feyder, 1931 - His Glorious Night; Lionel Barrymore, 1929)

MW, USA; Metro 1; 20.03.1931.

Anna Christie (Anna Christie; Jacques Feyder, 1930 - Anna Christie; Clarence Brown, 1929/1930) MW, USA; Lucerna 4; 3.04.1931.

Mys ztracených lidí (Menschen im Käfig; E. A. Dupont, 1930 - Cape Forlorn; E. A. Dupont, 1930) MW, Wielka Brytania; Fénix 1; 27.04.1931.

Poslední píseň (Liebeslied; Constantin J. David i Gennaro Righelli, 1930 - La canzone dell'amore; Gennaro Righelli, 1930) MW, Włochy; Valdek 1; 15.05.1931.

Znáš-li onen kraj pohádkový (Kennst Du das Land... Der Roman zweier Menschen; Constantin J. David, 1931 - Terra madre; Alessandro Blasetti, 1931) MW, Włochy; Avion 1; 3.07.1931.

Monsieur le Fox (Monsieur Le Fox; Hal Roach, 1931 - Men of the North; Hal Roach, 1930) MW, USA; Hollywood 1; 17.07.1931.

Čokoládová princezna (Kopfüber ins Glück; Hans Steinhoff, 1930 - Chacun sa chance; Hans Steinhoff i René Pujol, 1930) MW, Francja; Metro 1; 14.08.1931.

Jeho prítelkyně Anetta (Seine Freundin Annette; Felix Basch, 1930 - The Lady Lies; Hobart Henley, 1929) MW, USA; Avion 1; 14.08.1931.

Je Mary Duganová vinna? (Mordprozess Mary Dugan; Arthur Robison, 1930 - The Trial of Mary Dugan; Bayard Veiller, 1930) MW, USA; 2 (Koruna 1, Radio 1); 14.08.1931. Maska padá (Die Maske fällt; Wilhelm Dieterle, 1930 - The Way of All Men; Frank Lloyd, 1930) MW, USA; Olympic 2; 28.08.1931.

Snoubencova vdova (Die Bräutigamswitwe; Richard Eichberg, 1931 - Let's Love and Laugh; Richard Eichberg, 1931) MW, Wielka Brytania; Avion 3; 4.09.1931.

Přepojme na Hollywood (Wir schalten um auf Hollywood; Frank Reicher, 1931; z wykorzystaniem scen z filmu The Hollywood Revue of 1929; Charles Reisner, 1929) tylko niemiecka wersja, USA; Hollywood 1; 18.09.1931.

Va banque! (Va Banque. Alles oder Nichts; Erich Waschneck, 1930 - Le joker; Erich Waschneck, 1930) MW, Francja; Koruna 2; 25.09.1931.

Tropické noci (Tropennächte; Leo Mittler, 1930 - Dangerous Paradise; William A. Wellman, 1930) MW, USA; Radio 1; 2.10.1931.

Frigo, svůdce žen (Casanova wider Willen; Edward Brophy, 1931 - Parlor, Bedroom and Bath; Edward Sedgwick, 1931) MW, USA 5 (Radio 1, Roxy 2, Světozor 2); 30.10.1931.

Provdám se za svého muže (Ich heirate meinen Mann; E. W. Emo, 1931 - Her Wedding Night; Frank Tuttle, 1930) MW, USA, Passage 2; 27.11.1931.

Rozhodná noc (Die Nacht der Entscheidung; Dimitri Buchowetzki, 1931 - The Virtuous Sin; George Cukor i Louis Gasnier, 1930) MW, USA; 3 (Avion 2, Olympic 1); 27.11.1931.

Lidé za mř́žemi (Menschen hinter Gittern; Paul Fejos, 1930/1931 - The Big House; George Hill, 1930), MW, USA Alfa 3; 4.12.1931. 
Co s autem bez penéz (Ein Auto und kein Geld, Luise Fleck i Jacob Fleck, 1931) tylko niemiecka wersja, Niemcy; 4 (Hollywood 2, Světozor 2); 11.12.1931.

\section{2}

Koncert (Das Konzert; Leo Mittler, 1931 - Fashions in Love; Victor Schertzinger, 1929) MW, Francja; Světozor 1; 15.01.1932.

Netopýr (Die Fledermaus; Karel Lamač, 1931 - La Chauve-souris; Pierre Billon, Karel Lamač, 1931) MW, Francja; 8 (Fénix 2, Hollywood 3, Světozor 3); 29.01.1932.

Konec světa (Ende der Welt / La Fin du monde; Abel Gance, 1931) dubbing [?], Francja; Fénix 2; 11.03.1932.

Madame má vycházku (Madame hat Ausgang. Ein verliebtes Abenteuer; Wilhelm Thiele, 1931 - L'Amoureuse aventure; Wilhelm Thiele, 1931) MW, Francja; Metro 2; 8.04.1932.

Dnes líbá Paříž (Heut' küsst Paris / Die nackte Wahrheit; Karel Anton, 1931 - Nothing But the Truth; Victor Schertzinger, 1929) MW, Francja; Praha 2; 22.04.1932.

Seržant X (Sergeant X; Wladimir von Strischewski [= Vladimir Strijevski], 1931 - Le Sergent X; Vladimir Strijewski, 1931) MW, Francja; Alfa 2; 29.04.1932.

Marius (Zum goldenen Anker; Alexander Korda, 1931 - Marius; Alexander Korda i Marcel Pagnol, 1931) MW, Francja; Adria 1; 6.05.1932.

Matčino srdce (Seed; John M. Stahl, 1931) dubbing, USA; 2 (Hollywood 1, Skaut 1); 6.05.1932.

Dèvče z Montparnassu (Das Mädel vom Montparnasse; Hanns Schwarz, 1932 - La petite de Montparnasse; Hanns Schwarz i Max de Vaucorbeil, 1932) MW, Francja; Gaumont 2; 13.05.1932.

Dédic krve (Väter und Söhne; Victor Sjöström, 1930 - Markurells i Wadköping; Victor Sjöström, 1931) MW, Szwecja; Avion 2; 3.06.1932.

Dobrodružství gardového disstojníka (Kampf um die Frau (Die Tundra)); Friedrich von Maydell, 1931/1932 - Erämaan turvissa; Kalle Kaarnai - Friedrich von Maydell, 1931), MW, Finlandia; Praha 1; 22.07.1932.

Každá žena něčím vábí (Jede Frau hat etwas; Leo Mittler, 1930 - Honey; Wesley Ruggles, 1930) MW, USA; Passage 1; 5.08.1932.

Pochodem pochod (Schritt u. Tritt - I kantonnement; Lau Lauritzen, 1932) niemiecka synchronizacja, Dania; 3 (Radio 1, Světozor 2); 5.08.1932.

Muži kolem Lucie (Die Männer um Lucie; Alexander Korda, 1931 - Laughter; Harry d’Abbadie D’Arrast, 1930) MW, USA; 3 (Olympic 1, Skaut 2); 11.11.1932.

Bum bác! (Knall und Fall / Krudt med knald; Lau Lauritzen, 1931) niemiecka synchronizacja, Dania; 4 (Koruna 2, Louvre 2); 2.12.1932.

\section{3}

Ingagi (Ingagi; William Campbell, 1931) niemiecka synchronizacja, USA; Skaut 4; 17.02. 1933.

Stíny londýnských nocí (Der Greifer; Richard Eichberg, 1930 - Night Birds; Richard Eichberg, 1930) MW, Wielka Brytania; 4 (Koruna 2, Praha 2); 31.03.1933.

Dobrodružství krále Pausola (Die Abenteuer des Königs Pausole; Alexis Granowsky, 1933 - Les aventures du roi Pausole; Alexis Granowsky, 1933) MW, Francja; 6 (Kotva 3, 
Lucerna 3); 27.10.1933.

Pan Saval milionár (Rund um eine Million; Max Neufeld, 1933 - Une fois dans la vie; Max de Vaucorbeil, 1933) MW, Francja; 6 (Juliš 3, Passage 3); 1.12.1933.

\section{4}

Krok s cesty (Schritt vom Weg - The Man Who Came Back; Raoul Walsh, 1931) dubbing, USA; Světozor 1 ; 10.08.1934.

Yankee dvorním radou (Ein Yankee als Hofrat - A Connecticut Yankee; David Butler, 1931) dubbing, USA; Fénix 3; 10.08.1934.

Plující svět (Die schwimmende Welt, 1931/1932 - Transatlantic; William K. Howard, 1931) dubbing [?], USA; Juliš $1 ; 17.08 .1934$.

Inne wspomniane filmy (poza tytułami uwzględnionymi w wykazach przebojów oraz wersji niemieckich):

Aféra plukovníka Redla (Karel Anton, 1931); Erotikon (Gustav Machatý, 1929); Der Fall des Generalstabs - Oberst Redl (Karel Anton, 1931); Gehetzte Menschen (Friedrich Fehér, 1932); Hollywood Revue (The Hollywood Revue of 1929; Charles Reisner, 1929); Karneval umèlců (High Society Blues; David Butler, 1930); Paramount Revue (Paramount on Parade; Dorothy Arzner, Otto Brower, Edmund Goulding, Ernst Lubitsch i in..; reżyseria czeskich wstawek Charles de Rochefort, 1930); Ponorka S 13 (Men Without Women; John Ford, 1930); Pražské švadlenky (Přemysl Pražský, 1929); Sensace (Die vom Rummelplatz; Karel Lamač, 1930); Svět bez hranic (Julius Lébl, 1931); Štvaní lidé (Friedrich Fehér, 1933); Tajemství lekařovo (Julius Lébl, 1930); Tango pro tebe (Ein Tango für dich; Géza von Bolváry).

\section{Z czeskiego przełożył Leszek Engelking}

\section{Przypisy tłumacza}

* W roku 1932 wprowadzony został w Czechosłowacji system kontyngentowy, trzykrotnie nowelizowany i ustalający ostatecznie zasadę, że na każde pięć importowanych filmów biuro wynajmu musi zaoferować kinom jeden film krajowy. Za pozwolenie wwozu płaciło się od każdego filmu 20000 koron czechosłowackich. Na skutek wydania ustawy kontyngentowej i protestów Amerykanów przeciw niej, wycofano z Czechosłowacji filmy amerykańskie, z wyjątkiem produkcji małych, niezależnych wytworni.

** Czeskie i oryginalne tytuły znaleźć można w dołączonych do teksty artykułu tabelach.

*** Film znany w Polsce również pod tytułami C.K. marszałek polny i C.K.feldmarszałek.

**** W okresie międzywojenny często mówiono w Czechosłowacji o jednym języku czechosłowackim, zwłaszcza w dokumentach oficjalnych. 